Article

\title{
Geochemical Fractions of the Agricultural Soils of Southern Poland and the Assessment of the Potentially Harmful Element Mobility
}

\author{
Agnieszka Gruszecka-Kosowska ${ }^{1, * \mathbb{D}}$, Agnieszka Baran ${ }^{2}$, Katarzyna Mazur-Kajta $^{3}$ and \\ Tomasz Czech ${ }^{2}$ \\ 1 Faculty of Geology, Geophysics, and Environmental Protection, Department of Environmental Protection, \\ AGH University of Science and Technology, Al. Mickiewicza 30, 30-059 Kraków, Poland \\ 2 Faculty of Agriculture and Economics, Department of Agricultural and Environmental Chemistry, \\ University of Agriculture in Kraków, Al. A. Mickiewicza 21, 31-120 Kraków, Poland; \\ abaran2@ar.krakow.pl (A.B.); tomasz.czech@urk.edu.pl (T.C.) \\ 3 Faculty of Economics and Management, Department of International Economic Relations, Opole University \\ of Technology, ul. Prószkowska 76, 45-758 Opole, Poland; k.mazur@po.opole.pl \\ * Correspondence: agnieszka.gruszecka@agh.edu.pl
}

Received: 24 September 2019; Accepted: 29 October 2019; Published: 31 October 2019

\begin{abstract}
Surface samples (0-25 cm each) of agricultural soils were investigated in five Regions (voivodeships) of southern Poland. The mean Potentially Harmful Element (PHE) pseudototal content ranges were as follows (mg/kg): As 5.19-10.9, Cd 0.34-1.56, Co 1.92-6.70, Cr 9.05-25.7, Cu 8.74-69.4, $\mathrm{Hg}$ 0.001-0.08, Ni 3.93-19.9, Pb 20.3-183, Sb 0.80-1.42, Tl 0.04-0.17, and Zn 61.3-422. The PHE availability depended on $\mathrm{pH}$, the organic carbon $\left(\mathrm{C}_{\mathrm{org}}\right)$ content, and the pseudototal PHE content in soils. Exchangeable and acid soluble PHE contents $\left(\mathrm{BCR}_{\mathrm{F} 1}\right)$ determined in the Community Bureau of Reference (BCR) three-step sequential extraction procedure decreased in this order: $\mathrm{Cd}>\mathrm{Zn}>\mathrm{Co}>$ $\mathrm{Ni}=\mathrm{Sb}>\mathrm{Cu}>\mathrm{Tl}>\mathrm{As}>\mathrm{Cr}=\mathrm{Pb}$. Actually available PHE contents in pore water $\left(0.01 \mathrm{~mol} / \mathrm{dm}^{3}\right.$ $\mathrm{CaCl}_{2}$ ) ranged as follows: $\mathrm{Cd} 0.81-17 \%, \mathrm{Cr} 0-0.25 \%, \mathrm{Cu} 0.01-2.31 \%, \mathrm{Ni} 0.16-2 \%, \mathrm{~Pb} 0.2-0.49 \%$, and Zn $0.25-2.12 \%$. The potential soluble total content of PHEs in pore water $\left(0.05 \mathrm{~mol} / \mathrm{dm}^{3} \mathrm{Na}_{2}\right.$ EDTA $)$ ranged as follows: Cd 27-91\%, Cr 0.7-7.1\%, Cu 6.7-98\%, Ni 3.6-41\%, Pb 15-41\%, and Zn 3-34\%. The mobility factor (MF) values indicated $\mathrm{Cd}(31.6 \%)$ and $\mathrm{Zn}(21.0 \%)$ as the most mobile elements in soil. Other PHEs followed the order of $\mathrm{Co}>\mathrm{Ni}>\mathrm{Tl}>\mathrm{As}>\mathrm{Sb}>\mathrm{Cu}>\mathrm{Cr}>\mathrm{Pb}$, with the MF values $<10 \%$. The risk assessment code (RAC) values revealed a very high ecological risk of $\mathrm{Cd}$ and $\mathrm{Zn}$ in the Podkarpackie Region and a high ecological risk of $\mathrm{Cd}$ in the Regions of Opolskie, Ślaskie, Małopolskie, and Podkarpackie, and the same of $\mathrm{Zn}$ in the Opolskie and Ślaskie. The modified risk assessment code (mRAC) index pointed a very high potential of adverse effects in soils in the Podkarpackie and a medium potential in the Opolskie, Śląskie, Małopolskie, and Świętokrzyskie. The potential adverse effect risk, described by the individual contamination factor (ICF) factor, was the following in the Regions, in the decreasing order: $\mathrm{Cd}>\mathrm{Pb}>\mathrm{Sb}>\mathrm{Zn}>\mathrm{Co}>\mathrm{Cu}>\mathrm{Ni}>\mathrm{Tl}>$ As $>\mathrm{Cr}$, and the same as described by the global contamination factor (GCF) values: Opolskie $>$ Podkarpackie $>$ Świętokrzyskie $>$ Śląskie $>$ Małopolskie.
\end{abstract}

Keywords: mobility; ecological risk; MF factor; mRAC index; ICF factor; GCF factor

\section{Introduction}

Potentially harmful elements (PHEs) can pose a threat to living organisms due to their toxic and carcinogenic effects [1]. They are still considered to be some of the most hazardous groups of inorganic contaminants in the environment. Thirteen trace metals and metalloids are recognised to be priority 
pollutants [2], i.e., $\mathrm{Ag}$, $\mathrm{As}, \mathrm{Be}, \mathrm{Cd}, \mathrm{Cr}, \mathrm{Cu}, \mathrm{Hg}, \mathrm{Ni}, \mathrm{Pb}, \mathrm{Sb}, \mathrm{Se}, \mathrm{Tl}$, and $\mathrm{Zn}$. However, certain trace elements are beneficial for plant growth (for example $\mathrm{Zn}, \mathrm{Cu}, \mathrm{Cr}$, and $\mathrm{Co}$ ) or animal nutrition (for example $\mathrm{Co}, \mathrm{Cr}$, and $\mathrm{Se}$ ). Additionally, humans require certain trace elements. Those elements are generally divided into macro- and microelements [3]. Other metals, e.g., $\mathrm{Pb}$ and $\mathrm{Cd}$, are considered to be harmful to humans, even in low concentrations [4].

PHEs can occur in soils due to natural phenomena, e.g., weathering of the parent rock or metalliferous ores exposing metallic minerals. The most significant anthropogenic sources of PHE contamination include agriculture (fertilizers, animal manure, or pesticides), metallurgy (mining and smelting), energy production (leaded gasoline, battery production, or power generation), sewage sludge, and waste disposal [5,6]. Consequently, the contamination of agricultural soils has become a worldwide problem [4,7-16]. Similarly, the areas of southern Poland, being the objects of research, struggle with the problem of environmental pollution especially caused by coal, $\mathrm{Zn}, \mathrm{Pb}$, and $\mathrm{Cu}$ ores mining and processing, urban agglomerations, and intense traffic as was stated before by Gruszecka-Kosowska et al. [17].

Making references to the total PHE concentrations is the most common method of characterizing environmental pollution. For example, the United States Environmental Protection Agency (USEPA) human health risk assessment (HHRA) methodology is based on that approach. One has to have in mind that the total content of elements refers to concentrations of analyzed elements determined after a complete dissolution of the solid matrix with a combination of strong acids i.e., hydrofluoric acid (HF) as well as alkali solutions [18]. However, due to safety precautions HF procedure is not recommended for routine analysis. As an alternative to this procedure is pseudo-total digestion by aqua regia [19]. Although commonly used, aqua regia is often rated as a less suitable solvent for the estimation of the total amount of heavy metals in an environmental matrix [18]. Nevertheless, even high total or pseudototal concentrations of heavy metals do not always pose a threat to the environment. In environmental studies, the mobile portion of the element content gives more reliable information as to potential adverse effect risks for the environment and living organisms, while extraction procedures provide information on mobile and available portions of PHEs.

There are many definitions of contaminant bioavailability in the literature, and the debate on adopting precise definitions continues. It is considered as the fraction of the total contaminant in the interstitial water and soil particles that is available to the receptor organism [20]. Nevertheless, based on the investigations conducted by many scientists in the last 20 years, emphasizing that bioavailability should be considered as a dynamic process, strongly dependent on the type of organism, type of exposure, and metal speciation, as well as soil properties, three separate steps including the descriptions of bioavailability have evolved [21-23]. The first step represents the availability of PHEs in soils as a physico-chemically controlled desorption process, and the step is called environmental availability. The second step describes a physiologically controlled uptake process of PHEs by organisms and it is called environmental bioavailability. The third step is a physiologically induced effect, or accumulation of PHEs in living organisms, called toxicological bioavailability. Environmental availability, which is the object of the present study, depends on such soil properties, as e.g., texture, the contents of organic matter, clay minerals, or oxides, and soil $\mathrm{pH}$, as well as the total PHE content and PHE types. The period of PHE contact with the soil matrix is also essential. Besides dissolved free ions and molecules, the fraction in question may also include an amount of PHEs, combined either with dissolved organic matter (humic and fulvic acids) or inorganic anions $\left(\mathrm{Cl}^{-}, \mathrm{OH}^{-}, \mathrm{SO}_{4}{ }^{2-}\right.$, or $\mathrm{HCO}_{3}{ }^{-}$), especially under slightly acidic and alkaline conditions [23].

There are many measurement methods applied to determine bioavailable fractions. Several groups of chemical extraction procedures can be distinguished. Depending on the number of extraction steps, single or sequential extraction procedures are identified [19,20,24-26]. Depending on the type and solution strength, the following procedures are distinguished: acid extraction, extraction in chelating agents, and in buffered or unbuffered salt solutions [27]. The actual PHE quantities collected by plants from soil can be chemically measured via exchange by unbuffered salt mechanism, 
using $0.01 / 0.0025 / 0.001 \mathrm{~mol} / \mathrm{dm}^{3} \mathrm{CaCl}_{2}, 1 / 0.1 \mathrm{~mol} / \mathrm{dm}^{3} \mathrm{NaNO}_{3}$, or $1 \mathrm{~mol} / \mathrm{dm}^{3} \mathrm{NH}_{4} \mathrm{NO}_{3}$. The results of the extractions mentioned before reflect the actually available element contents in pore water. Those extraction procedures are suitable for highly mobile elements, i.e., $\mathrm{Cd}, \mathrm{Ni}, \mathrm{Zn}$. To measure the potentially available PHE contents, the methods of desorption by chelating agent extraction in $0.05 \mathrm{~mol} / \mathrm{dm}^{3}$ EDTA or $0.005 \mathrm{~mol} / \mathrm{dm}^{3}$ DTPA solutions, as well as extractions based on the exchange, with the application of strong acid in $0.43 \mathrm{~mol} / \mathrm{dm}^{3} \mathrm{HNO}_{3}$ or $0.1 / 0.5 \mathrm{~mol} / \mathrm{dm}^{3} \mathrm{HCl}$ solutions are applied. Those methods determine the potential soluble total element concentration in pore water, in respect of $\mathrm{Cd}, \mathrm{Cr}, \mathrm{Cu}, \mathrm{Ni}, \mathrm{Pb}$, and $\mathrm{Zn}$ [23]. Moreover, well developed and standardized bioavailability measurement methods are crucial for measurement results, as they lead to ecological and human health risk assessment of potential exposure to the PHE transfers in the soil-crop-human chain [23]. Certain soil leaching procedures described in the above mentioned references have been standardized or are considered to be standardized in various European countries for the soil remediation purposes, based on risk reduction [20,27].

As southern Poland is known for its productive soils [28], thus the previous research of Gruszecka-Kosowska et al. [17] was focused on the pseudototal PHE concentrations in the arable soils of southern Poland. However, as the knowledge about PHE bioavailable forms and their contents in the arable soils seems to be even more important in the context of PHE migration in the food chain. For that reason, the investigations of PHE environmental availability were the goal of the current studies. The investigations were the part of the larger project that was carried out on arable lands in five Regions of southern Poland where edible plants (i.e., vegetables, fruit, and cereals) were cultivated [17]. Detailed objectives of the current research included the following: (1) determination of the mobility using exchangeable and acid soluble $\left(\mathrm{BCR}_{\mathrm{F} 1}\right)$ contents determined in the Community Bureau of Reference (BCR) three-step sequential extraction procedure, actually available contents in pore water using $0.01 \mathrm{~mol} / \mathrm{dm}^{3} \mathrm{CaCl}_{2}$, and potentially available contents using $0.05 \mathrm{~mol} / \mathrm{dm}^{3} \mathrm{Na}_{2} \mathrm{EDTA}$ of selected PHEs (As, Cd, $\mathrm{Co}, \mathrm{Cr}, \mathrm{Cu}, \mathrm{Hg}, \mathrm{Ni}, \mathrm{Pb}, \mathrm{Sb}, \mathrm{Se}, \mathrm{Tl}$, and $\mathrm{Zn}$ ) in reference to the pseudototal element content in soils [17], (2) calculation of single and complex geochemical fractionation indices, and (3) determination of potential contamination of investigated agricultural soils by the selected PHEs in the respective Regions.

\section{Materials and Methods}

\subsection{Study Area}

The study area consisted of five Regions (voivodeships) located in southern Poland (Figure 1), from where 30 samples of agricultural soil from the depth of $0-25 \mathrm{~cm}$ each were collected as follows: four soil samples from the Opolskie, four samples from the Ślaskie, 12 samples from the Małopolskie, six samples from the Świętokrzyskie, and four samples from the Podkarpackie. The soil sampling locations were chosen in similar places where edible plants analyzed in further investigations were cultivated [17].

\subsection{Soil Sampling and Preparation}

As the current research was part of a larger project, the procedure of soil sampling and preparation was described in detail previously [17]. The soil samples were taken only in the arable soils where edible plants i.e., vegetables, fruits, and cereals, were cultivated and analyzed in the further investigations. Briefly, a total of 30 soil samples were collected in 2015 and 2016. Each soil sample (mass about $1 \mathrm{~kg}$ each) was collected from $1 \times 1 \mathrm{~m}$ square and consisted of five subsamples taken from the square corners and the diagonal intersection from the depth of 0-25 cm. Soil samples and their duplicates were air-dried at the room temperature $\left(25^{\circ} \mathrm{C}\right)$ and homogenized. Sample masses were reduced and were passed through a $2 \mathrm{~mm}$ sieve to remove plant parts and gravel before further analysis. 


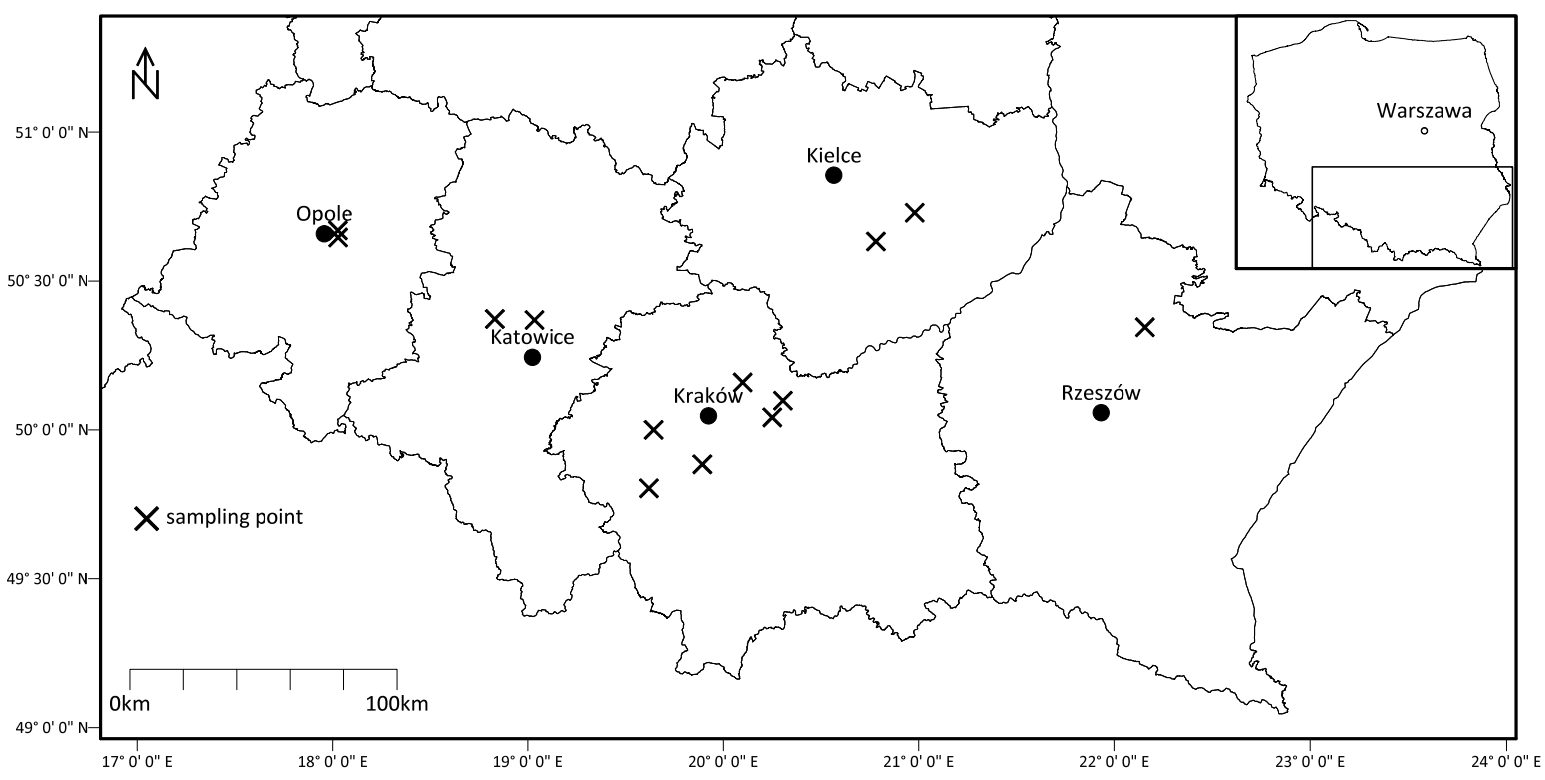

Figure 1. Agricultural soil-sampling site locations in the Regions of southern Poland (modified from [17]).

\subsection{Sample Analyses}

Active $\left(\mathrm{pH}_{\mathrm{H} 2 \mathrm{O}}\right)$ and potential $\left(\mathrm{pH}_{\mathrm{KCl}}\right) \mathrm{pH}$ values were determined on duplicate soil samples, as described previously [17]. The organic carbon $\left(\mathrm{C}_{\mathrm{org}}\right)$ content was determined, using the Tiurin method.

Investigated PHEs were extracted from $1 \mathrm{~g}$ of each soil sample during mineralization (DigiPREP-SCP Science Utilities, version 3.0, Quebec, QC, Canada) with aqua regia $\left(\mathrm{HNO}_{3}\right.$ and $\mathrm{HCl}$ at $3: 1 \mathrm{v} / \mathrm{v}$ ) for $2 \mathrm{~h}$ in the temperature $130^{\circ} \mathrm{C}$ and concentrations of $\mathrm{As}, \mathrm{Cd}, \mathrm{Co}, \mathrm{Cr}, \mathrm{Cu}, \mathrm{Hg}, \mathrm{Ni}$, $\mathrm{Pb}, \mathrm{Sb}, \mathrm{Se}, \mathrm{Tl}$, and $\mathrm{Zn}$ were determined by inductively coupled plasma-mass spectrometry ICP-MS (ELAN 6100; Perkin Elmer, Waltham, MA, USA), according to the USEPA 6020B [29] and PN-EN ISO 17294-2:2006 [30] Standard protocols.

The binding forms of PHEs were determined by the BCR sequential extraction procedure [31]. Briefly, $1 \mathrm{~g}$ of each soil sample in the $\mathrm{BCR}_{\mathrm{F} 1}$ step, $\mathrm{H}_{2} \mathrm{O}$ soluble and acid forms of PHEs (metals on exchangeable positions and bound with carbonates) were extracted with $0.11 \mathrm{~mol} / \mathrm{dm}^{3} \mathrm{CH}_{3} \mathrm{COOH}, \mathrm{pH}$ $=2.85$; in the $\mathrm{BCR}_{\mathrm{F} 2}$ step, reducible forms of PHEs (metals bound with oxides and hydro-oxides of Fe and $\mathrm{Mn}$ ) were extracted with $0.1 \mathrm{~mol} / \mathrm{dm}^{3} \mathrm{NH}_{2} \mathrm{OH} \cdot \mathrm{HCl}, \mathrm{pH}=2$; and in the $\mathrm{BCR}_{\mathrm{F} 3}$ step, oxidizable forms of PHEs (metals bound with sulphides and organic matter) were extracted with (1) $2 \times 30 \%$ $\mathrm{H}_{2} \mathrm{O}_{2} ; 1 \mathrm{~h}, 85^{\circ} \mathrm{C}$ and (2) $1 \mathrm{~mol} / \mathrm{dm}^{3} \mathrm{CH}_{3} \mathrm{COONH}_{4}, \mathrm{pH}=2$, respectively. Content of PHEs in residual fraction $\left(\mathrm{BCR}_{\mathrm{F} 4}\right)$ was determined in the residues remaining after $\mathrm{BCR}_{\mathrm{F} 3}$ step at the same aqua regia digestion. For the determination of the PHE mobility their contents in the $\mathrm{BCR}_{\mathrm{F} 1}$ fraction were used in further analysis.

Actually available PHE contents in pore water were extracted with $20 \mathrm{~cm}^{3}$ of $0.01 \mathrm{~mol} / \mathrm{dm}^{3}$ $\mathrm{CaCl}_{2}$ and potential soluble total PHE concentration in pore water were extracted with $0.05 \mathrm{~mol} / \mathrm{dm}^{3}$ $\mathrm{Na}_{2}$ EDTA from $2 \mathrm{~g}$ of each soil sample, followed by shaking for $2 \mathrm{~h}[27,32,33]$. After extraction samples were centrifuged at $3000 \mathrm{rpm}$ for $10 \mathrm{~min}$, and supernatants were separated from precipitate through a filter. The contents of bioavailable contents of PHEs were determined, using the ICP-OES (Inductively Coupled Plasma Optical Emission Spectroscopy) method on an Optima 7300 DV (Perkin-Elmer).

\subsection{Quality Control}

The quality control was previously described in detail in Gruszecka-Kosowska et al. [17]. Soil analyses were performed under the standard certified analytical quality control procedure according to PN-EN ISO 17294-1:2007 [34] and were also measured, using inductively coupled 
plasma-optical emission spectroscopy ICP-OES (OPTIMA 7300DV; Perkin Elmer, Waltham, MA, USA), according to the USEPA 6020B [29] and PN-EN ISO 11885:2009 [35] protocols. The recovery rate from analyzed at the same time certified reference material CRM (soil ERM ${ }^{\circledR}-C C 141$ ) was between $81 \%$ and $112 \%$ for the majority of the PHEs analyzed, except for As, Co, Cr, and $\mathrm{Ni}$. In that method, reagent blanks and duplicates of each of the three samples were used for quality assurance and quality control. All the reagents used in the laboratory analysis were analytically pure. The results of the sample examinations were within the allowable error change values. Analytical bias was statistically insignificant $(p=0.05)$. ICP-MS and ICP-OES system precision parameters were satisfactory, verified by six different solution injections. Rh was used as an internal standard. Element correction equations were used for each element to minimize the impact of interferences in the ICP-MS analysis.

The limit of detection (LOD) values of the investigated PHEs were as follows: As $<0.001 \mathrm{mg} / \mathrm{dm}^{3}$, $\mathrm{Cd}<0.003 \mathrm{mg} / \mathrm{dm}^{3}, \mathrm{Co}<0.0002 \mathrm{mg} / \mathrm{dm}^{3}, \mathrm{Cr}<0.005 \mathrm{mg} / \mathrm{dm}^{3}, \mathrm{Cu}<0.001 \mathrm{mg} / \mathrm{dm}^{3}, \mathrm{Hg}<0.0001$ $\mathrm{mg} / \mathrm{dm}^{3}, \mathrm{Ni}<0.001 \mathrm{mg} / \mathrm{dm}^{3}, \mathrm{~Pb}<0.0001 \mathrm{mg} / \mathrm{dm}^{3}, \mathrm{Sb}<0.0002 \mathrm{mg} / \mathrm{dm}^{3}, \mathrm{Se}<0.01 \mathrm{mg} / \mathrm{dm}^{3}, \mathrm{Tl}<0.0001$ $\mathrm{mg} / \mathrm{dm}^{3}$, and $\mathrm{Zn}<0.001 \mathrm{mg} / \mathrm{dm}^{3}$.

Recovery compares the total metal content with the sequential extraction steps, according to Equation (1) [36,37]

$$
\text { Recovery }=\left(\frac{\sum_{i=1}^{n} \text { sequential extraction steps }}{\text { pseudototal concentration }}\right) \times 100 \%
$$

The recovery values ranged as follows: As $87-156 \%$, Cd 92-151\%, Co 69-156\%, Cr 62-151\%, Cu 89-107\%, Ni 68-119\%, Pb 90-131\%, Sb 90-129\%, Tl 84-147\%, and Zn 79-127\%.

\subsection{Statistical Analysis}

The results were verified statistically, using the Statistica 12 software package. The differences between the means were analyzed by the ANOVA test at a significance level of 0.05. Principal Component Analysis (PCA) was preformed to establish the relationship and behavior of PHEs in soils.

\subsection{Soil Quality}

The permissible levels of metals and metalloids, determined in the Regulation of the Polish Minister of the Environment on how to conduct pollution assessment on the surface of the earth of 1 September 2016 [38], were used to indicate potential contamination of agricultural soils by the investigated PHEs in the respective Regions of southern Poland. Threshold values were chosen, depending on the clay content (fraction $<0.02 \mathrm{~mm}$ ) in soil, described as a subgroup of ground, from II-1 to II-3. Since not all of PHEs were specified in the Polish law, the Canadian soil quality guidelines for the protection of environmental and human health [39] were also applied.

\subsection{Fractionation Indices}

The mobility factor (MF), the risk assessment code (mRAC), and the individual contamination factor (ICF) were applied as single fractionation indices in our research. It is commonly known that the total or pseudototal element concentration is not entirely available to biota. Thus, when determining soil contamination, it is better to take into consideration mobile and available contents of particular PHEs that may pose a real threat to the living organisms. Therefore, we focused in our study on the fractionation indices more than on the indices based on the pseudototal concentration of individual PHEs. The mobility factor (MF), the risk assessment code (RAC), and the global contamination factor (GCF), selected from among single fractionation indices, were applied in our investigations. The modified risk assessment code (mRAC) index and the global contamination factor (GCF), as selected from the complex fractionation indices, were applied. A brief description of the calculation of the geochemical fractionation indices applied in the study is given in Table 1. 
Table 1. Description of the geochemical fractionation indices applied in the study.

\begin{tabular}{|c|c|c|c|c|c|}
\hline Index & Formula & Explanations & Limit Values & Classification & Reference \\
\hline \multicolumn{6}{|l|}{ Single Indices } \\
\hline $\begin{array}{l}\text { Mobility factor } \\
\text { MF }\end{array}$ & $\begin{array}{c}\mathrm{MF}= \\
\mathrm{BCRF} 1 \\
(\mathrm{BCRF} 1+\mathrm{BCRF} 2+\mathrm{BCRF} 3+\mathrm{BCRF} 4) \\
\times 100 \%\end{array}$ & $\begin{array}{l}\mathrm{BCR}_{\mathrm{F} 1}-\mathrm{BCR}_{\mathrm{F} 4}-\text { content of } \\
\text { single } \mathrm{PHE} \text { in each } \\
\text { fraction in } \% \text { according to } \\
\text { the } \mathrm{BCR} \text { procedure }\end{array}$ & No limit values & $\begin{array}{c}\text { The higher MF value the higher } \\
\text { PHE mobility }\end{array}$ & {$[40,41]$} \\
\hline $\begin{array}{l}\text { Risk assessment code } \\
\text { RAC }\end{array}$ & content of $\mathrm{BCR}_{\mathrm{F} 1}$ & $\begin{array}{l}\mathrm{BCR}_{\mathrm{F} 1}-\text { content of single } \\
\mathrm{PHE} \text { in exchangeable and } \\
\text { carbonate fractions in } \%\end{array}$ & $\begin{array}{c}\% \mathrm{BCR}_{\mathrm{F} 1}<1 \\
1<\% \mathrm{BCR}_{\mathrm{F} 1}<10 \\
11<\% \mathrm{BCR}_{\mathrm{F} 1}<30 \\
31<\% \mathrm{BCR}_{\mathrm{F} 1}<50 \\
\% \mathrm{BCR}_{\mathrm{F} 1}>50\end{array}$ & $\begin{array}{c}\text { No risk } \\
\text { Low risk } \\
\text { Medium risk } \\
\text { High risk } \\
\text { Very high risk }\end{array}$ & [42] \\
\hline $\begin{array}{l}\text { Individual contamination factor } \\
\text { ICF }\end{array}$ & $\mathrm{ICF}=\frac{\mathrm{BCRF} 1+\mathrm{BCRF} 2+\mathrm{BCRF} 3}{\mathrm{BCRF} 4}$ & $\begin{array}{l}\text { PMF-content in potential } \\
\text { mobile fractions } \\
\left(\mathrm{BCR}_{\mathrm{F} 1}-\mathrm{BCR}_{\mathrm{F} 3}\right) \\
\text { according to the } \mathrm{BCR} \\
\text { procedure }\end{array}$ & No limit values & $\begin{array}{l}\text { The higher value the higher } \\
\text { ecological risk }\end{array}$ & [43] \\
\hline \multicolumn{6}{|l|}{ Complex Indices } \\
\hline $\begin{array}{c}\text { Modified risk assessment codem } \\
\text { RAC }\end{array}$ & $\mathrm{mRAC}=\frac{\sum_{\mathrm{i}=1}^{\mathrm{n}} \operatorname{Tri} \mathrm{RACi}}{\sum_{\mathrm{i}=1}^{\mathrm{n}} \operatorname{Tri}}$ & $\begin{array}{l}\mathrm{RAC}_{\mathrm{i}}-\text { percentage of each } \\
\text { PHE in potential mobile } \\
\text { fractions; } \mathrm{Tr}_{\mathrm{i}} \text { - toxic } \\
\text { response of the PHE; } \\
\mathrm{n}-\text { number of PHEs }\end{array}$ & $\begin{array}{c}\operatorname{mRAC}<1 \\
1 \leq \mathrm{mRAC}<10 \\
10 \leq \mathrm{mRAC}<30 \\
30 \leq \mathrm{mRAC}<50 \\
\mathrm{mRAC} \geq 50\end{array}$ & $\begin{array}{l}\text { No potential of adverse effect } \\
\text { Low potential of adverse effect } \\
\text { Medium potential of adverse effect } \\
\text { High potential of adverse effect } \\
\text { Very high potential of adverse effect }\end{array}$ & {$[37,44-48]$} \\
\hline $\begin{array}{l}\text { Global contamination factor } \\
\text { GCF }\end{array}$ & $\mathrm{GCF}=\Sigma \mathrm{ICF}$ & $\begin{array}{c}\text { ICF-individual } \\
\text { contamination factor of } \\
\text { single PHE }\end{array}$ & No limit values & $\begin{array}{l}\text { The higher value the higher } \\
\text { ecological risk }\end{array}$ & {$[36,43]$} \\
\hline
\end{tabular}




\section{Results and Discussion}

\subsection{Physico-Chemical Characteristics of Soils}

As described previously [17] in southern Poland, where investigations were conducted, soils are generally classified as cambisols, podzols, and luvisols according to the World Reference Base for Soil Resources (IUSS Working Group 2015). The measured pH values classified the investigated agricultural soil samples as neutral in the Opolskie $\left(\mathrm{pH}_{\mathrm{H} 2 \mathrm{O}}\right.$ range: 6.8-7.2, mean: 7.0) and Ślaskie $\left(\mathrm{pH}_{\mathrm{H} 2 \mathrm{O}}\right.$ range: $6.8-8.3$, mean: 7.0$)$ and slightly acidic in the Małopolskie $\left(\mathrm{pH}_{\mathrm{H} 2 \mathrm{O}}\right.$ range: $4.8-7.9$, mean: 6.50), Świętokrzyskie $\left(\mathrm{pH}_{\mathrm{H} 2 \mathrm{O}}\right.$ range: 5.4-7.2, mean: 6.4), and Podkarpackie $\left(\mathrm{pH}_{\mathrm{H} 2 \mathrm{O}}\right.$ range: 5.6-6.8, mean: 6.2) Regions. The content of $\mathrm{C}_{\text {org }}(\%)$ in investigated soil samples ranged as follows, with mean values in parentheses: Opolskie 1.12-3.46 (2.24), Śląskie 1.39-2.13 (1.83), Małopolskie 0.60-3.48 (1.56), Świętokrzyskie 0.62-1.37 (1.02), and Podkarpackie 1.26-1.98 (1.57). The clay content (fraction $<0.02 \mathrm{~mm}$, in \%) were taken from the Main Inspectorate of Environmental Protection [49] and ranged as follows, with mean values in parentheses: Opolskie 7.00-23.0 (15.0), Ślaskie 28.0-50.0 (33.5), Małopolskie 26.0-42.0 (37.3), Świętokrzyskie 8.00-12.0 (10.7), and Podkarpackie 9.00-26.0 (17.5). Basic statistical PHE characteristics in the investigated regions is given on Figure 2. The Se content in all soil samples of each Region was < LOD. Minimum concentrations were also < LOD for Cd, $\mathrm{Hg}$, and $\mathrm{Tl}$ in the Świettokrzyskie, for $\mathrm{Cd}$ and $\mathrm{Hg}$ in the Małopolskie and Podkarpackie, and for $\mathrm{Hg}$ in the Opolskie. As for the mean pseudototal content, the decreasing orders of single PHEs were as follows: As: Śląskie $>$ Podkarpackie $>$ Świętokrzyskie $>$ Opolskie $>$ Małopolskie; Cd: Śląskie $>$ Małopolskie $>$ Świętokrzyskie $>$ Opolskie $>$ Podkarpackie; Co: Małopolskie $>$ Świętokrzyskie $>$ Śląskie $>$ Opolskie $>$ Podkarpackie; Cr: Śląskie $>$ Małopolskie $>$ Świętokrzyskie = Podkarpackie $>$ Opolskie; Cu: Śląskie $>$ Małopolskie $>$ Świętokrzyskie $>$ Opolskie $>$ Podkarpackie; Hg: Małopolskie $>$ Ślaskie $>$ Świętokrzyskie $>$ Opolskie $=$ Podkarpackie; Ni: Śląskie $>$ Opolskie $>$ Świętokrzyskie $>$ Podkarpackie $>$ Małopolskie; $\mathrm{Pb}$ : Śląskie $>$ Małopolskie $>$ Opolskie $>$ Świętokrzyskie $>$ Podkarpackie; Sb: Małopolskie $>$ Ślasskie $>$ Opolskie $>$ Świętokrzyskie $>$ Podkarpackie; Tl: Opolskie $>$ Śląskie $>$ Świętokrzyskie $>$ Podkarpackie $>$ Małopolskie; and Zn: Małopolskie $>$ Śląskie $>$ Opolskie $>$ Podkarpackie $>$ Świętokrzyskie. 


$$
20
$$

As

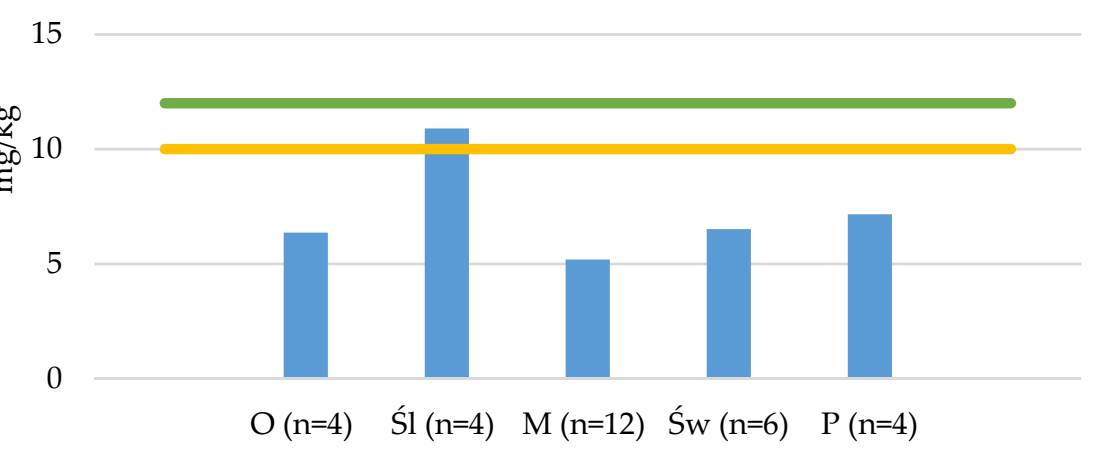

40

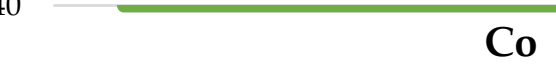

32

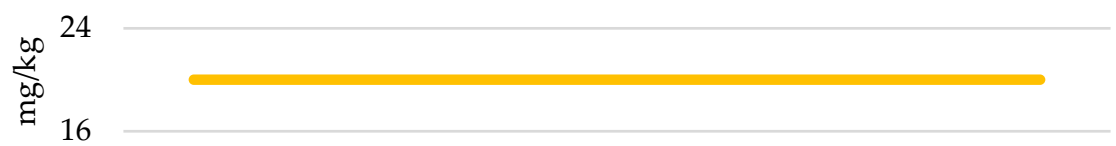

8

0

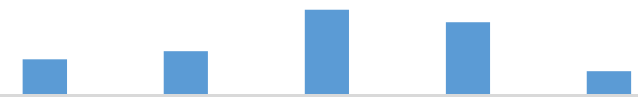

$\mathrm{O}(\mathrm{n}=4) \quad S ́ 1(\mathrm{n}=4) \quad \mathrm{M}(\mathrm{n}=12) \quad$ Św $(\mathrm{n}=6) \quad \mathrm{P}(\mathrm{n}=4)$
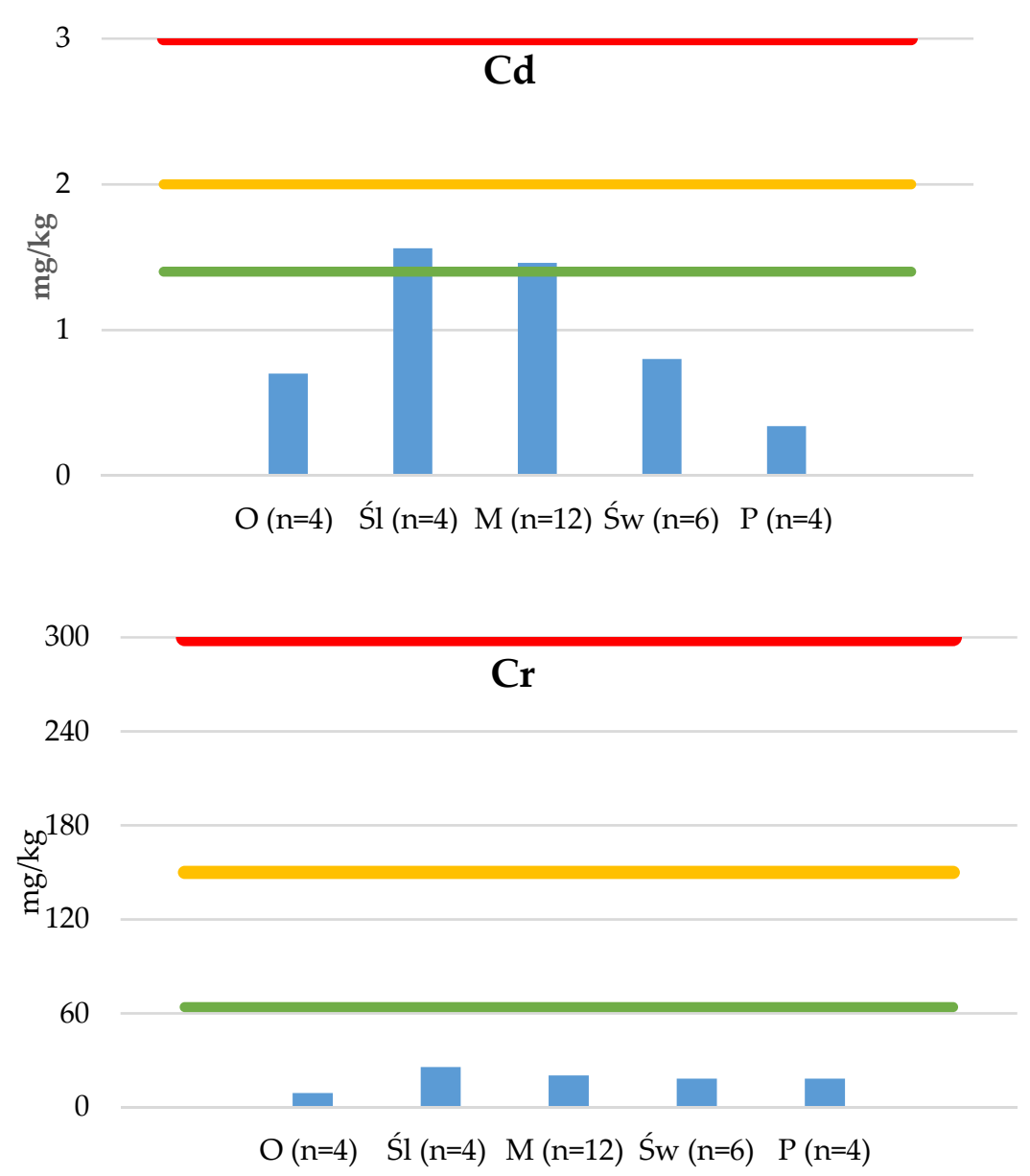

Figure 2. Cont. 

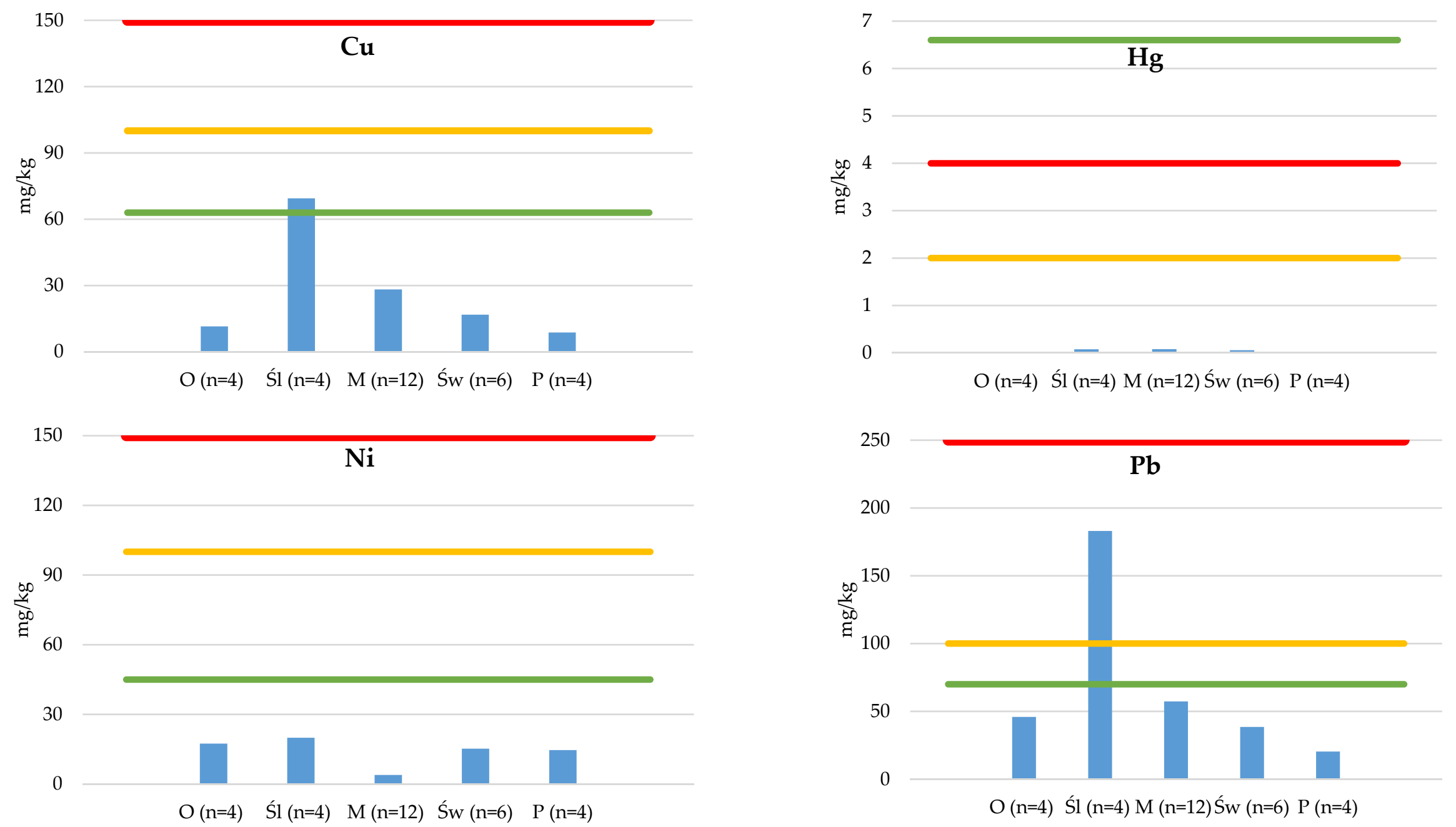

Figure 2. Cont. 
20.00

16.00

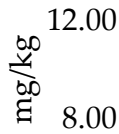

4.00

0.00

$\mathrm{O}(\mathrm{n}=4) \quad$ Śl $(\mathrm{n}=4) \quad \mathrm{M}(\mathrm{n}=12) \quad$ Św $(\mathrm{n}=6) \quad \mathrm{P}(\mathrm{n}=4)$

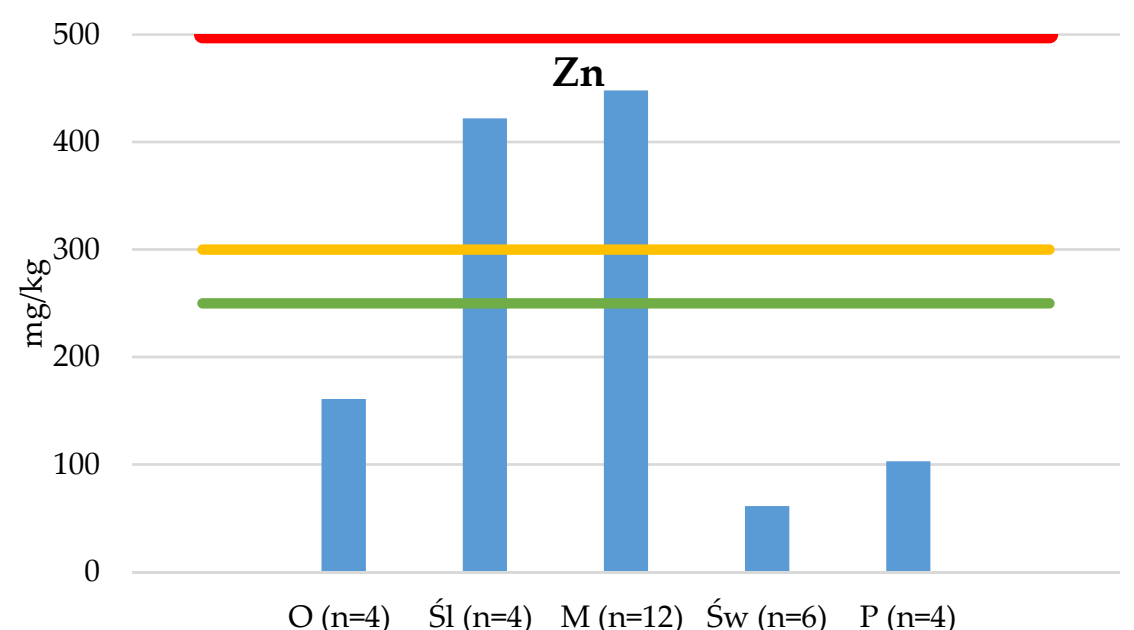

$\mathrm{Sb}$$$
1
$$$$
8
$$$$
\underbrace{\infty}_{0.0} 0.6
$$$$
\text { घ } 0.4
$$

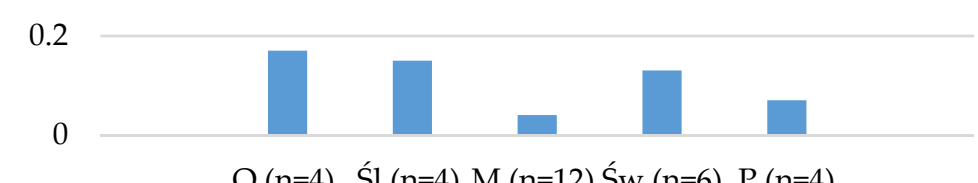

$O(n=4)$ Śl $(n=4) M(n=1)$ Św $(n=6) P(n=4)$

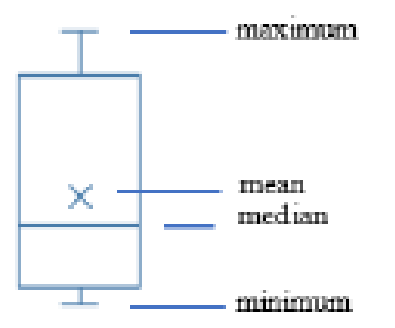

soil subgroup II-1 [38]

soil subgroup II-2 [38]

Canadian soil quality guidelines [39]

Figure 2. Pseudototal Potentially Harmful Element (PHE) contents in the agricultural soils in the Regions of southern Poland and soil quality; O—Opolskie, Śl_Slaskie, M-Małopolskie, Św-Świętokrzyskie, P-Podkarpackie. 
Our tests of the pseudototal PHE contents in agricultural soil samples confirmed the results of the research conducted previously in the Regions of SE Poland: in Ślaskie [28,50-53], of S Poland: in Małopolskie [33,54-58], and of SE Poland: in Podkarpackie [59] and in Świętokrzyskie [60]. Our results were also comparable to those obtained within the frame of the National Environmental Monitoring System: chemical monitoring of arable soils, performed by the IUNG Institute of Soil Science and Plant Cultivation in Puławy [49]; five measurement-control profiles of arable soils in the Małopolskie (No. 417 Wadowice-Chocznia, No. 421 Brzyczyna, No. 349 Grojec, No. 353 Pleszów, No. 355 Posądza), two profiles in the Ślaskie (No. 335 Piekary Ślaskie, No. 333 Mokre); two profiles in the Opolskie (No. 323 Grabówka, No. 321 Grodzisko); two profiles in the Świętokrzyskie (No. 367 Rzędów, No. 369 Niedziałki); and two profiles in the Podkarpackie (No. 387 Dębno, No. 385 Nisko). Our results were also referred to the geochemical values derived from the existing geochemical atlases of the Małopolskie [61] and Upper Silesia [62,63].

\subsection{Soil Quality}

Investigated arable soil samples quality determination results are presented in Figure 2. Considering clay content [49] and measured $\mathrm{pH}$ investigated soil samples from Opolskie, Świętokrzyskie and Podkarpackie regions were classified to the soil subgroup II-1 and from Ślaskie and Małopolskie regions to the soil subgroup II-2, according to the Regulation of the Polish Minister of the Environment [38]. The consequence of such division was that for group II-1 permissible PHE levels were lower than for group II-2. Nevertheless, in reference to the Polish regulations, none of the PHEs exceeded the permissible values. Consequently, the investigated soils were suitable for edible plant cultivation. However, when considering the recommended maximum concentrations specified in the Canadian soil quality guidelines for the protection of environmental and human health, it was found that the guideline values were exceeded about twice for $\mathrm{Cd}, \mathrm{Cu}, \mathrm{Pb}$, and $\mathrm{Zn}$ in the Slaskie and $\mathrm{Cd}$ and $\mathrm{Zn}$ in the Małopolskie, as well as for $\mathrm{Pb}$ in the Ślaskie and $\mathrm{Zn}$ in the Ślaskie and Małopolskie.

\subsection{Assessment of Potential Bioavailable Forms of PHEs}

\subsubsection{Multi-Stage Sequential Extraction: BCR Binding Forms of Soils}

In the context of environmental and health protection, not only the total or pseudototal PHE content but also the bioavailable PHE content is crucial. For that reason, the results of the BCR extraction procedure of the investigated PHEs as the relative ratio of a fraction to the summarized extracted fractions expressed in $\%$ are presented in Figure 3. The BCR results were not available for $\mathrm{Hg}$ and Se, while the pseudototal concentrations of Se were $<$ LOD in all the investigated samples and those of $\mathrm{Hg}$ in the majority of the investigated samples. The PHE mobility was as follows, in the decreasing order: 

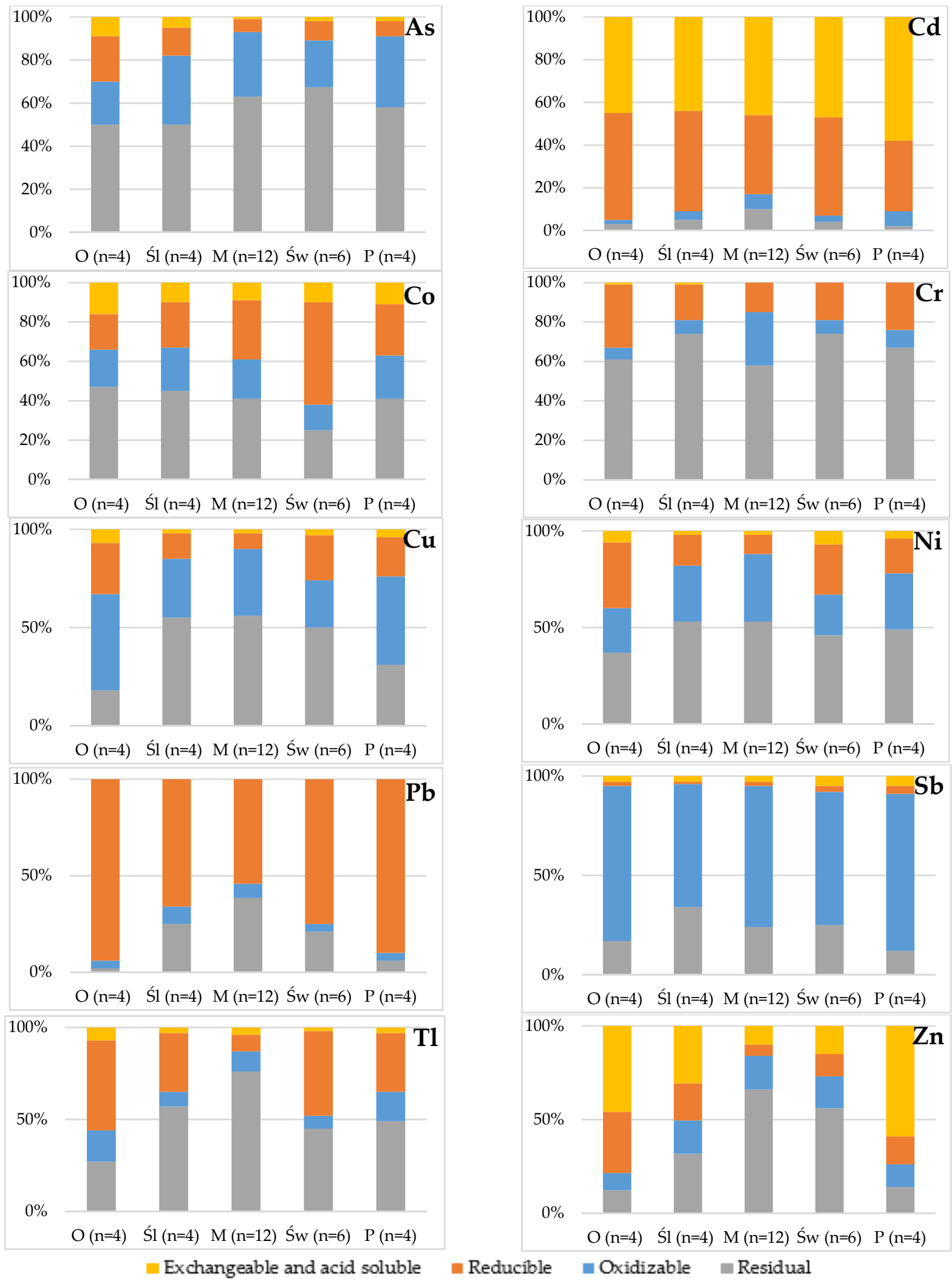

Figure 3. PHE content (\%) from the Community Bureau of Reference (BCR) extraction procedure as the relative ratio of a fraction to the summarized extracted fractions expressed in the agricultural soils of southern Poland; O-Opolskie, Śl—Śląskie, M-Małopolskie, Św-Świętokrzyskie, P-Podkarpackie.

Exchangeable and acid soluble $\left(\mathrm{BCR}_{\mathrm{F} 1}\right): \mathrm{Cd}>\mathrm{Zn}>\mathrm{Co}>\mathrm{Ni}=\mathrm{Sb}>\mathrm{Cu}>\mathrm{Tl}>\mathrm{As}>\mathrm{Cr}=\mathrm{Pb}$, 
Reducible $\left(\mathrm{BCR}_{\mathrm{F2}}\right): \mathrm{Pb}>\mathrm{Cd}>\mathrm{Tl}>\mathrm{Co}>\mathrm{Cr}>\mathrm{Ni}>\mathrm{Cu}>\mathrm{Zn}>\mathrm{As}>\mathrm{Sb}$,

Oxidizable $\left(\mathrm{BCR}_{\mathrm{F} 3}\right): \mathrm{Sb}>\mathrm{Cu}>\mathrm{As}>\mathrm{Ni}>\mathrm{Co}>\mathrm{Zn}>\mathrm{Tl}>\mathrm{Cr}>\mathrm{Pb}>\mathrm{Cd}$,

Residual $\left(\mathrm{BCR}_{\mathrm{F} 4}\right)$ : $\mathrm{Cr}>\mathrm{As}>\mathrm{Tl}>\mathrm{Ni}>\mathrm{Cu}>\mathrm{Co}>\mathrm{Zn}>\mathrm{Sb}>\mathrm{Pb}>\mathrm{Cd}$.

Since $\mathrm{BCR}_{\mathrm{F} 1}$ represented the mobile PHE fraction contents, bound with exchangeable and acid soluble forms, the absolute contents of the investigated soil samples were also given (mean values in mg/kg), by Regions: Opolskie: As 0.57, Cd 0.32, Co 0.45, Cr 0.09, Cu 0.81, Ni 1.19, Pb < LOD, Sb 0.04, Tl 0.01, Zn 72.5; Ślaskie: As 0.55, Cd 0.69, Co 0.35, Cr 0.26, Cu 1.39, Ni 0.08, Pb < LOD, Sb 0.04, Tl 0.005, Zn 131; Małopolskie: As 0.05, Cd 0.67, Co 0.60, Cr < LOD, Cu 0.56, Ni 0.30, Pb < LOD, Sb 0.04, Tl 0.002, Zn 44.8; Świętokrzyskie: As 0.07, Cd 0.38, Co 0.57, Cr < LOD, Cu 0.50, Ni 1.02, Pb < LOD, $\mathrm{Sb}$ 0.05, Tl 0.003, Zn 9.20; Podkarpackie: As 0.14, Cd 0.20, Co 0.21, Cr < LOD, Cu 0.35, Ni 0.58, Pb < $\mathrm{LOD}, \mathrm{Sb} 0.04, \mathrm{Tl} 0.002, \mathrm{Zn} 60.8$. The mobile PHE content $\left(\mathrm{BCR}_{\mathrm{F} 1}\right)$ decreased in particular Regions as follows: As: Opolskie $>$ Śląskie $>$ Podkarpackie $>$ Małopolskie $=$ Świętokrzyskie; Cd: Podkarpackie $>$ Świętokrzyskie $>$ Małopolskie $>$ Opolskie $>$ Śląskie; Co: Opolskie $>$ Podkarpackie $>$ Śląskie $=$ Świętokrzyskie $>$ Małopolskie; Cr: Opolskie $=$ Ślaskie $>$ Małopolskie $=$ Świętokrzyskie $=$ Podkarpackie; $\mathrm{Cu}$ : Opolskie $>$ Podkarpackie $>$ Świętokrzyskie $>$ Małopolskie $>$ Śląskie; Ni: Świętokrzyskie $>$ Opolskie $>$ Podkarpackie $>$ Śląskie $=$ Małopolskie; Sb: Świętokrzyskie $>$ Podkarpackie $>$ Opolskie $=$ Ślaskie $=$ Małopolskie; Tl: Opolskie $>$ Małopolskie $>$ Śląskie $=$ Podkarpackie $>$ Świętokrzyskie; Zn: Podkarpackie $>$ Opolskie $>$ Śląskie $>$ Świętokrzyskie $>$ Małopolskie. For $\mathrm{Pb}$ in all Regions and for $\mathrm{Cr}$ in the Małopolskie, Świetokrzyskie, and Podkarpackie, the mobility associated with the acid soluble $\left(\mathrm{BCR}_{\mathrm{F} 1}\right)$ extraction step was $<<1 \%$. The content of potentially mobile PHEs (the sum of the $\mathrm{BCR}_{\mathrm{F} 1}$, $\mathrm{BCR}_{\mathrm{F} 2}$, and $\mathrm{BCR}_{\mathrm{F} 3}$ fractions) decreased in the investigated Regions as follows: As: Ślaskie $>$ Opolskie $>$ Podkarpackie $>$ Świętokrzyskie $>$ Małopolskie; Cd: Ślaskie $>$ Małopolskie $>$ Świętokrzyskie $>$ Opolskie $>$ Podkarpackie; Co: Świętokrzyskie $>$ Małopolskie $>$ Śląskie $>$ Opolskie $>$ Podkarpackie; Cr: Małopolskie $>$ Śląskie $>$ Podkarpackie $>$ Świętokrzyskie $>$ Opolskie; Cu: Śląskie $>$ Małopolskie $>$ Opolskie $>$ Świętokrzyskie $>$ Podkarpackie; Ni: Opolskie $>$ Śląskie $>$ Świętokrzyskie $>$ Podkarpackie $>$ Małopolskie; Pb: Śląskie > Opolskie $>$ Małopolskie $>$ Świętokrzyskie > Podkarpackie; Sb: Opolskie $>$ Małopolskie $>$ Śląskie $>$ Świętokrzyskie $>$ Podkarpackie; Tl: Opolskie $>$ Świętokrzyskie $>$ Śląskie $>$ Podkarpackie $>$ Małopolskie; Zn: Ślaskie $>$ Małopolskie $>$ Opolskie $>$ Podkarpackie $>$ Świętokrzyskie. The majority of the PHE contents consisted in the mobile and potentially mobile forms of $\mathrm{Cd}, \mathrm{Co}, \mathrm{Ni}$, $\mathrm{Pb}$, and $\mathrm{Sb}$ in southern Poland, it is in $\mathrm{BCR}_{\mathrm{F} 1}$ to $\mathrm{BCR}_{\mathrm{F} 3}$ fractions). As to $\mathrm{As}, \mathrm{Cr}$, and $\mathrm{Cu}$ (except for the Ślaskie, Małopolskie and Świętokrzyskie), Tl (except for the Opolskie and Świętokrzyskie), and Zn (except for the Opolskie, Ślaskie, and Podkarpackie), the highest proportions of the PHE contents were in the residual form $\left(\mathrm{BCR}_{\mathrm{F} 4}\right.$ step), which may have indicated a natural origin of the elements connected with lithogenic sources.

\subsubsection{One-Step Extraction}

The contents of the bioavailable forms of PHEs, identified in the soil samples of the investigated Regions, are presented in Table 2. Among the single extractants, lower element concentrations were obtained upon applying $\mathrm{CaCl}_{2}$, in contrast to $\mathrm{Na}_{2}$ EDTA. Those results were comparable to the results reported by other authors, since the unbuffered salt solution of $\mathrm{CaCl}_{2}$, simulating natural soil solutions, was useful for the assessment of the ecological relevance of elements [19]. Moreover, Pinto et al. [64] found that $\mathrm{CaCl}_{2}$ was a thinly diluted salt solution and it could only be used as extractant for the elements that existed in exchangeable forms and water-soluble forms. However, the other single extraction procedure, using $\mathrm{Na}_{2}$ EDTA, isolated a higher content of potentially mobile soil fraction of PHEs. In our studies, we found some differences between the contents of bioavailable forms of PHEs in the analyzed soils. However, significant differences were demonstrated only in respect of the contents of $\mathrm{Cr}, \mathrm{Cu}, \mathrm{Pb}\left(\mathrm{CaCl}_{2}\right)$ and $\mathrm{Cd}, \mathrm{Cu}, \mathrm{Cr}\left(\mathrm{Na}_{2}\right.$ EDTA) (with significant differences at $\left.p<0.05\right)$ (Table 2). The highest contents of the mobile forms of PHEs were observed in the soil samples collected from the Ślaskie, except for $\mathrm{Ni}$ and $\mathrm{Zn}, \mathrm{Cd}\left(\mathrm{CaCl}_{2}\right)$, with the lowest in the samples from the Podkarpackie, except for $\mathrm{Cu}\left(\mathrm{Na}_{2} \mathrm{EDTA}\right), \mathrm{Ni}\left(\mathrm{CaCl}_{2}\right)$, and $\mathrm{Zn}$. The potential bioavailable PHE fractions, extracted by 
$\mathrm{CaCl}_{2}$, ranged as follows: $\mathrm{Cd}$ from $0.81 \%$ (Ślaskie) to $17 \%$ (Świętokrzyskie); $\mathrm{Cr}$ from $0 \%$ (Podkarpackie and Ślaskie) to $0.25 \%$ (Opolskie); Cu from $0.01 \%$ (Śląskie) to 2.31\% (Opolskie); Ni from 0.16\% (Ślaskie) to $2 \%$ (Świętokrzyskie); Pb from $0.2 \%$ (Ślaskie) to $0.49 \%$ (Opolskie); and $\mathrm{Zn}$ from $0.25 \%$ (Ślaskie) to $2.12 \%$ (Świettokrzyskie) of the pseudototal contents of those elements. The distribution of the mobile fractions extracted by $\mathrm{Na}_{2}$ EDTA ranged as follows: Cd from 27\% (Ślaskie) to 91\% (Małopolskie); $\mathrm{Cr}$ from $0.7 \%$ (Podkarpackie) to 7.1\% (Opolskie); Cu from 6.7\% (Ślaskie) to 98\% (Opolskie); Ni from 3.6\% (Ślaskie) to 41\% (Małopolskie); Pb from 15\% (Małopolskie) to 41\% (Śląkie); and Zn from 3\% (Małopolskie) to 34\% (Świętokrzyskie) of the pseudototal contents of the PHEs. Among the analyzed PHEs, Cd was potentially the most mobile and bioavailable element in the studied soils. Moreover, the highest mobility of PHEs was found in the soils collected in the Świętokrzyskie and Opolskie Regions, and the lowest in the Śląskie.

Table 2. Forms of PHEs that are bioavailable for plants in the agricultural soils in the Regions of southern Poland.

\begin{tabular}{|c|c|c|c|c|c|c|}
\hline $\begin{array}{l}\text { PHEs } \\
\text { Mean } \\
(\mathrm{mg} / \mathrm{kg})\end{array}$ & Reagent & $\begin{array}{c}\text { Opolskie } \\
(n=4)\end{array}$ & $\begin{array}{l}\text { Śląskie } \\
(n=4)\end{array}$ & $\begin{array}{l}\text { Małopolskie } \\
\quad(n=12)\end{array}$ & $\begin{array}{l}\text { Świętokrzyskie } \\
\quad(n=6)\end{array}$ & $\begin{array}{l}\text { Podkarpackie } \\
(n=4)\end{array}$ \\
\hline \multirow{3}{*}{$\mathrm{Cd}$} & $\mathrm{CaCl}_{2}$ & 0.05 & 0.06 & 0.05 & 0.08 & 0.03 \\
\hline & $\mathrm{Na}_{2}$ EDTA * & 0.36 & 2.48 & 0.37 & 0.23 & 0.17 \\
\hline & $\mathrm{BCR}_{\mathrm{F} 1}$ & 0.32 & 0.69 & 0.67 & 0.38 & 0.2 \\
\hline \multirow{3}{*}{$\mathrm{Cr}$} & $\mathrm{CaCl}_{2} *$ & 0.023 & $<$ LOD & 0.003 & 0.003 & $<\mathrm{LOD}$ \\
\hline & $\mathrm{Na}_{2}$ EDTA * & 0.64 & 0.25 & 0.20 & 0.15 & 0.13 \\
\hline & $\mathrm{BCR}_{\mathrm{F} 1}$ & 0.09 & 0.26 & $<\mathrm{LOD}$ & $<\mathrm{LOD}$ & $<\mathrm{LOD}$ \\
\hline \multirow{3}{*}{$\mathrm{Cu}$} & $\mathrm{CaCl}_{2} *$ & 0.27 & 0.01 & 0.01 & 0.01 & 0.01 \\
\hline & $\mathrm{Na}_{2}$ EDTA * & 11.3 & 4.75 & 3.29 & 1.18 & 1.73 \\
\hline & $\mathrm{BCR}_{\mathrm{F} 1}$ & 0.81 & 1.39 & 0.56 & 0.5 & 0.35 \\
\hline \multirow{3}{*}{$\mathrm{Ni}$} & $\mathrm{CaCl}_{2}$ & 0.12 & 0.03 & 0.05 & 0.31 & 0.04 \\
\hline & $\mathrm{Na}_{2}$ EDTA & 2.00 & 0.76 & 1.75 & 1.38 & 0.54 \\
\hline & $\mathrm{BCR}_{\mathrm{F} 1}$ & 1.19 & 0.08 & 0.3 & 1.02 & 0.58 \\
\hline \multirow{3}{*}{$\mathrm{Pb}$} & $\mathrm{CaCl}_{2} *$ & 0.22 & 0.04 & 0.05 & 0.05 & 0.04 \\
\hline & $\mathrm{Na}_{2}$ EDTA & 15.5 & 70.9 & 9.32 & 6.25 & 4.68 \\
\hline & $\mathrm{BCR}_{\mathrm{F} 1}$ & $<\mathrm{LOD}$ & $<$ LOD & $<\mathrm{LOD}$ & $<\mathrm{LOD}$ & $<$ LOD \\
\hline \multirow{3}{*}{$\mathrm{Zn}$} & $\mathrm{CaCl}_{2}$ & 1.32 & 0.79 & 1.34 & 1.30 & 2.08 \\
\hline & $\mathrm{Na}_{2}$ EDTA & 51.7 & 95.6 & 13.8 & 5.49 & 34.9 \\
\hline & $\mathrm{BCR}_{\mathrm{F} 1}$ & 72.5 & 131 & 44.8 & 9.2 & 60.8 \\
\hline
\end{tabular}

$<$ LOD below the limit of detection, * significant at $p \leq 0.05$.

\subsubsection{Comparison of the Results Achieved by the Extraction Methods Applied}

As it was mentioned in the Introduction above, three different extraction procedures in the investigations were applied. To determine the actually available PHE contents in soils, we applied extraction with $0.01 \mathrm{~mol} / \mathrm{dm}^{3} \mathrm{CaCl}_{2}$, as unbuffered salt solution, and $0.11 \mathrm{~mol} / \mathrm{dm}^{3} \mathrm{CH}_{3} \mathrm{COOH}$, representing the first fraction of the $\mathrm{BCR}$ extraction procedure $\left(\mathrm{BCR}_{\mathrm{F} 1}\right)$. To determine the potentially available PHE contents in soil, $0.05 \mathrm{~mol} / \mathrm{dm}^{3}$ EDTA and the sum of $\mathrm{BCR}_{\mathrm{F} 1}$ to $\mathrm{BCR}_{\mathrm{F} 3}$ fractions of the $\mathrm{BCR}$ extraction procedure were applied. As the literature specified, $0.05 \mathrm{~mol} / \mathrm{dm}^{3}$ EDTA was recommended for agricultural and environmental studies and $0.01 \mathrm{~mol} / \mathrm{dm}^{3} \mathrm{CaCl}_{2}$ for soil-plant uptake studies [19], while the $0.11 \mathrm{~mol} / \mathrm{dm}^{3} \mathrm{CH}_{3} \mathrm{COOH}$ fraction described the exchangeable PHEs, bound with carbonates [65]. As one can see in Table 2, the increasing amounts of individual PHEs extracted in the Regions of southern Poland were as follows: Opolskie: $\mathrm{Cd}, \mathrm{Cr}, \mathrm{Cu}$ and Ni: $\mathrm{CaCl}_{2}<$ $\mathrm{BCR}_{\mathrm{F} 1}<\mathrm{Na}_{2} \mathrm{EDTA} ; \mathrm{Zn}: \mathrm{CaCl}_{2}<\mathrm{Na}_{2} \mathrm{EDTA}<\mathrm{BCR}_{\mathrm{F} 1}$; and Pb: $\mathrm{BCR}_{\mathrm{F} 1}<\mathrm{CaCl}_{2}<\mathrm{Na}_{2}$ EDTA; Ślaskie: $\mathrm{Cd}, \mathrm{Cu}$, and Ni: $\mathrm{CaCl}_{2}<\mathrm{BCR}_{\mathrm{F} 1}<\mathrm{Na}_{2}$ EDTA; $\mathrm{Cr}$ and $\mathrm{Zn}: \mathrm{CaCl}_{2}<\mathrm{Na}_{2} \mathrm{EDTA}_{2}<\mathrm{BCR}_{\mathrm{F} 1} ; \mathrm{Pb}: \mathrm{BCR}_{\mathrm{F} 1}$ $<\mathrm{CaCl}_{2}<\mathrm{Na}_{2}$ EDTA; Małopolskie: $\mathrm{Cu}$ and Ni: $\mathrm{CaCl}_{2}<\mathrm{BCR}_{\mathrm{F} 1}<\mathrm{Na}_{2}$ EDTA; $\mathrm{Cd}$ and $\mathrm{Zn}: \mathrm{CaCl}_{2}<$ $\mathrm{Na}_{2}$ EDTA $<\mathrm{BCR}_{\mathrm{F} 1}$; $\mathrm{Cr}$ and Pb: $\mathrm{BCR}_{\mathrm{F} 1}<\mathrm{CaCl}_{2}<\mathrm{Na}_{2}$ EDTA; Świętokrzyskie: $\mathrm{Cu}$ and Ni: $\mathrm{CaCl}_{2}<$ $\mathrm{BCR}_{\mathrm{F} 1}<\mathrm{Na}_{2} \mathrm{EDTA}$; $\mathrm{Cd}$ and $\mathrm{Zn}: \mathrm{CaCl}_{2}<\mathrm{Na}_{2} \mathrm{EDTA}<\mathrm{BCR}_{\mathrm{F} 1}$; $\mathrm{Cr}$ and $\mathrm{Pb}: \mathrm{BCR}_{\mathrm{F} 1}<\mathrm{CaCl}_{2}<\mathrm{Na}_{2} \mathrm{EDTA}$; Podkarpackie: $\mathrm{Cr}$ and $\mathrm{Cu}: \mathrm{CaCl}_{2}<\mathrm{BCR}_{\mathrm{F} 1}<\mathrm{Na}_{2} \mathrm{EDTA}$; $\mathrm{Cd}$, Ni, and $\mathrm{Zn}: \mathrm{CaCl}_{2}<\mathrm{Na}_{2} \mathrm{EDTA}_{2}<\mathrm{BCR}_{\mathrm{F} 1}$; and $\mathrm{Pb}: \mathrm{BCR}_{\mathrm{F} 1}<\mathrm{CaCl}_{2}<\mathrm{Na}_{2} \mathrm{EDTA}$. Generally, the increasing amounts of extracted individual PHEs 
were as follows in southern Poland: $\mathrm{Cd}, \mathrm{Cr}, \mathrm{Cu}$, and Ni: $\mathrm{CaCl}_{2}<\mathrm{BCR}_{\mathrm{F} 1}<\mathrm{Na}_{2} \mathrm{EDTA}_{\mathrm{Z}} \mathrm{Zn}$ : $\mathrm{CaCl}_{2}<$ $\mathrm{Na}_{2}$ EDTA $<\mathrm{BCR}_{\mathrm{F} 1}$; and $\mathrm{Pb}: \mathrm{BCR}_{\mathrm{F} 1}<\mathrm{CaCl}_{2}<\mathrm{Na}_{2}$ EDTA. Thus, the contents of PHEs extracted in the $\mathrm{CaCl}_{2}$ reagent were equivalent to the amounts that were taken up by plants, the PHE contents extracted with $\mathrm{Na}_{2}$ EDTA determined the amounts responsible for the environmental risk, and the potentially mobile PHE contents determined by the BCR extraction procedure indicated environmental threat.

The analysis of the correlations between the contents of the bioavailable forms extracted by $\mathrm{CaCl}_{2}$, $\mathrm{Na}_{2}$ EDTA, and $\mathrm{BCR}_{\mathrm{F} 1}$ is presented in Table 3. The highest correlations were observed between the PHEs extracted by $\mathrm{Na}_{2}$ EDTA, followed by those obtained by $\mathrm{CaCl}_{2}$, which confirmed that those contents were bioavailable. $\mathrm{Cr}$ and $\mathrm{Cu}$, and partially $\mathrm{Cd}, \mathrm{Pb}$, and $\mathrm{Zn}$, were the PHEs that correlated with themselves in different extraction procedures. Under the same reagent procedure, strong positive correlations were observed between the following pairs of $\mathrm{PHEs}: \mathrm{Cr}-\mathrm{Pb}$ and $\mathrm{Cu}-\mathrm{Pb}$ in $\mathrm{CaCl}_{2}$ extraction; $\mathrm{Cd}-\mathrm{Cu}, \mathrm{Cr}-\mathrm{Cu}, \mathrm{Cd}-\mathrm{Pb}, \mathrm{Cr}-\mathrm{Pb}, \mathrm{Cu}-\mathrm{Pb}, \mathrm{Cu}-\mathrm{Zn}$, and $\mathrm{Pb}-\mathrm{Zn}$ in $\mathrm{Na}_{2}$ EDTA extraction; and $\mathrm{Pb}-\mathrm{Zn}$ in $\mathrm{BCR}_{\mathrm{F} 1}$. A medium positive correlation was observed as follows: $\mathrm{Cd}-\mathrm{Ni}, \mathrm{Cd}-\mathrm{Zn}, \mathrm{Cr}-\mathrm{Cu}, \mathrm{Cr}-\mathrm{Ni}, \mathrm{Cu}-\mathrm{Ni}$, $\mathrm{Ni}-\mathrm{Pb}, \mathrm{Ni}-\mathrm{Zn}$, and $\mathrm{Pb}-\mathrm{Zn}$ in $\mathrm{CaCl}_{2}$ extraction; $\mathrm{Cd}-\mathrm{Cr}, \mathrm{Cd}-\mathrm{Ni}, \mathrm{Cd}-\mathrm{Zn}, \mathrm{Cr}-\mathrm{Ni}$, and $\mathrm{Cr}-\mathrm{Zn}$ in $\mathrm{Na}_{2}$ EDTA extraction; and $\mathrm{Cd}-\mathrm{Pb}, \mathrm{Cu}, \mathrm{Pb}$, and $\mathrm{Cu}-\mathrm{Zn}$ in $\mathrm{BCR}_{\mathrm{F} 1}$, with a medium negative correlation of $\mathrm{Ni}-\mathrm{Pb}$. Among different extraction procedures, medium positive correlations were observed in the following pairs of PHEs: $\mathrm{Cr}-\mathrm{Cr}, \mathrm{Cr}-\mathrm{Cu}$ between $\mathrm{CaCl}_{2}-\mathrm{Na}_{2}$ EDTA and medium negative correlation of Ni-Zn; $\mathrm{Cd}-\mathrm{Cd}, \mathrm{Cr}-\mathrm{Cr}, \mathrm{Cu}-\mathrm{Cr}, \mathrm{Cr}-\mathrm{Pb}$ between $\mathrm{CaCl}_{2}-\mathrm{BCR}_{\mathrm{F} 1}$; and $\mathrm{Cu}-\mathrm{Zn}, \mathrm{Ni}-\mathrm{Ni}, \mathrm{Pb}-\mathrm{Pb}, \mathrm{Pb}-\mathrm{Zn}$ and $\mathrm{Zn}-\mathrm{Zn}$ between $\mathrm{Na}_{2}$ EDTA-BCR ${ }_{\mathrm{F} 1}$. 
Table 3. Analysis of the correlation between the contents of bioavailable forms $(p \leq 0.05)$.

\begin{tabular}{|c|c|c|c|c|c|c|c|c|c|c|c|c|c|c|c|c|c|c|c|}
\hline & & \multicolumn{6}{|c|}{$\mathrm{CaCl}_{2}$} & \multicolumn{6}{|c|}{$\mathrm{Na}_{2}$ EDTA } & \multicolumn{6}{|c|}{$\mathbf{B C R}_{\mathrm{F} 1}$} \\
\hline & & $\mathrm{Cd}$ & $\mathrm{Cr}$ & $\mathrm{Cu}$ & $\mathbf{N i}$ & $\mathbf{P b}$ & $\mathrm{Zn}$ & $\mathrm{Cd}$ & $\mathrm{Cr}$ & $\mathrm{Cu}$ & $\mathbf{N i}$ & $\mathrm{Pb}$ & Zn & $\mathrm{Cd}$ & $\mathrm{Cr}$ & $\mathrm{Cu}$ & $\mathrm{Ni}$ & $\mathrm{Pb}$ & $\mathrm{Zn}$ \\
\hline \multirow{6}{*}{$\mathrm{CaCl}_{2}$} & $\mathrm{Cd}$ & 1.00 & & & & & & & & & & & & & & & & & \\
\hline & $\mathrm{Cr}$ & 0.17 & 1.00 & & & & & & & & & & & & & & & & \\
\hline & $\mathrm{Cu}$ & 0.24 & $\underline{0.69}$ & 1.00 & & & & & & & & & & & & & & & \\
\hline & $\mathrm{Ni}$ & $\underline{0.59}$ & $\underline{0.53}$ & $\underline{0.50}$ & 1.00 & & & & & & & & & & & & & & \\
\hline & $\mathbf{P b}$ & $\overline{0.35}$ & $\overline{0.73}$ & $\overline{0.84}$ & $\underline{0.59}$ & 1.00 & & & & & & & & & & & & & \\
\hline & $\mathrm{Zn}$ & $\underline{0.69}$ & 0.25 & 0.42 & $\overline{0.62}$ & $\underline{0.53}$ & 1.00 & & & & & & & & & & & & \\
\hline \multirow{6}{*}{$\mathrm{Na}_{2} \mathrm{EDT}$} & $\mathrm{Cd}$ & 0.12 & 0.10 & 0.14 & -0.15 & -0.09 & -0.30 & 1.00 & & & & & & & & & & & \\
\hline & $\mathrm{Cr}$ & -0.13 & $\underline{0.55}$ & $\underline{0.50}$ & 0.00 & 0.27 & -0.22 & $\underline{0.66}$ & 1.00 & & & & & & & & & & \\
\hline & $\mathrm{A}^{\mathrm{Cu}}$ & -0.23 & $\overline{0.18}$ & $\overline{0.25}$ & -0.26 & -0.07 & -0.34 & $\overline{0.79}$ & 0.80 & 1.00 & & & & & & & & & \\
\hline & ${ }^{A} \mathrm{Ni}$ & -0.32 & 0.33 & 0.07 & 0.01 & -0.08 & $-\underline{0.51}$ & $\underline{0.51}$ & 0.59 & 0.44 & 1.00 & & & & & & & & \\
\hline & $\mathrm{Pb}$ & 0.08 & 0.20 & 0.30 & -0.15 & 0.06 & $-\overline{0.22}$ & $\overline{0.87}$ & $\overline{0.76}$ & 0.84 & 0.30 & 1.00 & & & & & & & \\
\hline & $\mathrm{Zn}$ & -0.12 & 0.04 & 0.27 & -0.28 & 0.07 & -0.08 & $\underline{0.63}$ & $\underline{0.62}$ & 0.82 & 0.12 & 0.72 & 1.00 & & & & & & \\
\hline \multirow{6}{*}{$\mathrm{BCR}_{\mathrm{F} 1}$} & $\mathrm{Cd}$ & 0.52 & -0.20 & 0.04 & 0.06 & -0.01 & 0.16 & 0.46 & -0.06 & 0.12 & -0.24 & 0.38 & 0.19 & 1.00 & & & & & \\
\hline & $\mathrm{Cr}$ & $\overline{0.14}$ & $\underline{0.67}$ & $\underline{0.53}$ & 0.46 & $\underline{0.62}$ & 0.27 & 0.05 & 0.43 & 0.21 & 0.07 & 0.15 & 0.23 & -0.02 & 1.00 & & & & \\
\hline & $\mathrm{Cu}$ & 0.27 & $\overline{0.27}$ & $\overline{0.40}$ & 0.38 & $\overline{0.28}$ & 0.38 & 0.32 & 0.31 & 0.43 & -0.10 & 0.43 & 0.36 & 0.41 & 0.47 & 1.00 & & & \\
\hline & $\mathrm{Ni}$ & -0.05 & 0.18 & -0.09 & 0.33 & -0.06 & -0.17 & -0.04 & -0.07 & -0.14 & $\underline{0.51}$ & -0.29 & -0.39 & 0.05 & 0.15 & -0.00 & 1.00 & & \\
\hline & $\mathrm{Pb}$ & 0.43 & 0.09 & 0.38 & 0.13 & 0.24 & 0.28 & 0.45 & 0.28 & 0.39 & $\overline{-0.33}$ & 0.67 & $\underline{0.50}$ & $\underline{0.52}$ & 0.13 & 0.59 & $-\underline{0.56}$ & 1.00 & \multirow[b]{2}{*}{1.00} \\
\hline & $\mathrm{Zn}$ & 0.19 & -0.06 & 0.31 & -0.07 & 0.17 & 0.26 & 0.37 & 0.27 & $\underline{0.51}$ & -0.33 & $\underline{0.51}$ & $\overline{0.83}$ & $\overline{0.43}$ & 0.28 & $\overline{0.52}$ & $-\overline{0.44}$ & 0.70 & \\
\hline
\end{tabular}

$0<\mathrm{r}<0.3$ very low correlation; $0.3 \leq \mathrm{r}<0.5$ low correlation; $0.5 \leq \mathrm{r}<0.7$ medium correlation; $0.7 \leq \mathrm{r}<0.9$ strong correlation; $0.9 \leq \mathrm{r}<1$ very strong correlation. 


\subsection{Principal Component Analysis (PCA) Analyses}

The Principal Component Analysis (PCA), performed in respect of the soil properties and the mobile PHE fraction, once PHEs were extracted by $\mathrm{CaCl}_{2}$ and $\mathrm{Na}_{2} \mathrm{EDTA}$, indicated similar behavior of PHEs in the examined soil samples (Table 4). PCA allowed us to extract two principal components (PCs), explaining the total variance of the dataset, from 56.9\% (Małopolskie) to $89.3 \%$ (Ślaskie). In the soil samples collected in the Opolskie Region, $\mathrm{PC} 1$ explaining $50.1 \%$ of the total variance had significant positive loadings on clay; $\mathrm{C}_{\text {org }} ; \mathrm{Cr}$ and $\mathrm{Ni}\left(\mathrm{CaCl}_{2}\right) ; \mathrm{Cd}, \mathrm{Cr} \mathrm{Cu}$, and $\mathrm{Ni}\left(\mathrm{Na}_{2} \mathrm{EDTA}\right)$, with negative loadings on $\mathrm{pH}$ and $\mathrm{Zn}\left(\mathrm{Na}_{2} \mathrm{EDTA}\right)$. PC2 explaining $34.9 \%$ of the total variance, with a strong positive loading for the total content of $\mathrm{Cr} ; \mathrm{Cu} ; \mathrm{Ni} ; \mathrm{Cu}\left(\mathrm{CaCl}_{2}\right) ; \mathrm{Zn}\left(\mathrm{Na}_{2} \mathrm{EDTA}\right)$ and negative loadings on the pseudototal contents of $\mathrm{Cd}$ and $\mathrm{Pb}\left(\mathrm{Na}_{2}\right.$ EDTA) (Table 3). The high loadings for clay, $\mathrm{C}_{\text {org }}$ and $\mathrm{pH}$ suggested the impact on the mobility of trace element in the studied soils. However, the pseudototal contents also played an essential role in the mobility of $\mathrm{Cu}, \mathrm{Pb}$, and $\mathrm{Zn}$. In the soils collected from the Ślaskie Region, with PC1 explaining $51.1 \%$ of the total variance, had a strong positive loading for $\mathrm{C}_{\text {org }}$, the pseudototal content of $\mathrm{Cd}$ and $\mathrm{Pb} ; \mathrm{Cu}$ and $\mathrm{Pb}\left(\mathrm{CaCl}_{2}\right) ; \mathrm{Pb}$ and $\mathrm{Zn}\left(\mathrm{Na}_{2} \mathrm{EDTA}\right)$, and a significant negative loading for clay and $\mathrm{Ni}$ (pseudototal content, $\mathrm{CaCl}_{2}$ ) (Table 4). The combination of properties in PC1 suggested the importance of $\mathrm{C}_{\mathrm{org}}$, with clay and the pseudototal content of $\mathrm{Pb}$ and $\mathrm{Ni}$ influencing the behavior of $\mathrm{Pb}$ and $\mathrm{Ni}$ in soils, respectively. PC2, explaining $38.2 \%$ and more of the total variance, had significant positive loadings on $\mathrm{pH} ; \mathrm{Cr}, \mathrm{Ni}$ and $\mathrm{Cu}\left(\mathrm{Na}_{2} \mathrm{EDTA}\right)$, and negative loadings on the pseudototal content of $\mathrm{Cr}, \mathrm{Cu}, \mathrm{Zn} ; \mathrm{Cd}$ and $\mathrm{Zn}\left(\mathrm{CaCl}_{2}\right)$. The results indicated that $\mathrm{Zn}$ mobility was dependent on $\mathrm{pH}$, clay, and content of $\mathrm{C}_{\mathrm{org}}$, as well as the pseudototal $\mathrm{Zn}$ content. In the soils collected from the Małopolskie Region, the first component (PC1) accounted for $35.1 \%$ of the total variance, with a strong positive loading for all metal contents extracted by $\mathrm{CaCl}_{2}$, and negative loading with $\mathrm{pH}$. PC2, explaining only $21.9 \%$ of the total variance, with a negative loading for all element contents extracted by $\mathrm{Na}_{2}$ EDTA. The results indicated that the mobility of trace elements depended on $\mathrm{pH}$. In the soils collected from the Świętokrzyskie Region, PC1 explained $56.9 \%$ of the total variance and had strong positive loadings $(>0.70)$ on the pseudototal content of $\mathrm{Cu}, \mathrm{Ni}, \mathrm{Cd}$, and the mobile forms of all elements (except $\mathrm{Cu}, \mathrm{Pb}, \mathrm{Zn}-\mathrm{Na}_{2} \mathrm{EDTA}$ ), with strong negative loadings on $\mathrm{pH}$, clay, and $\mathrm{C}_{\text {org }}$ (Table 4). PC2 explained $20.7 \%$ of the total variance, with a strong positive loading for pseudototal content of $\mathrm{Zn}, \mathrm{Pb}$, and their mobile contents extracted by $\mathrm{Na}_{2}$ EDTA. In the soils collected from the Podkarpackie Region, the first component (PC1) accounted for $57.2 \%$ of the total variance, with a strong positive loading on $\mathrm{pH}, \mathrm{C}_{\text {org }}$, the pseudototal content of $\mathrm{Cu}, \mathrm{Ni}, \mathrm{Cu}, \mathrm{Pb}\left(\mathrm{CaCl}_{2}\right)$, and all element contents extracted by $\mathrm{Na}_{2}$ EDTA, as well as negative loading with $\mathrm{Cd}\left(\mathrm{CaCl}_{2}\right)$ (Table 3). $\mathrm{PC} 2$, explaining $28.6 \%$ of the total variance with a negative loading for clay and the pseudototal content of $\mathrm{Cr}$ and a positive loading on the pseudototal content of $\mathrm{Pb}, \mathrm{Zn}$, and the mobile forms of $\mathrm{Zn}$ extracted by $\mathrm{CaCl}_{2}$. The results indicated that the mobility of PHEs generally depended on the $\mathrm{pH}$ and $\mathrm{C}_{\text {org }}$ contents, while the mobility of $\mathrm{Cu}$ and $\mathrm{Zn}$ depended on the pseudototal contents of those elements in soils. $\mathrm{Cr}$ extracted by $\mathrm{CaCl}_{2}$ was not treated by the PC analysis due to the fact that the $\mathrm{Cr}(\mathrm{III})$ and $\mathrm{Cr}(\mathrm{VI})$ forms were not investigated separately. 
Table 4. Component matrix of variables $(n=30)$.

\begin{tabular}{|c|c|c|c|c|c|c|c|c|c|c|}
\hline \multirow{2}{*}{ Variables } & \multicolumn{2}{|c|}{ Opolskie } & \multicolumn{2}{|c|}{ Śląskie } & \multicolumn{2}{|c|}{ Małopolskie } & \multicolumn{2}{|c|}{ Świętokrzyskie } & \multicolumn{2}{|c|}{ Podkarpackie } \\
\hline & PCA1 & PCA2 & PCA1 & PCA2 & PCA1 & PCA2 & PCA1 & PCA2 & PCA1 & PCA2 \\
\hline $\mathrm{pH}_{\mathrm{KCl}}$ & -0.99 . & 0.04 & 0.41 & 0.86 & -0.92 & -0.05 & -0.88 & -0.09 & 0.79 & -0.46 \\
\hline clay & 0.79 & 0.61 & -0.89 & 0.41 & -0.49 & 0.01 & -0.69 & 0.13 & 0.48 & -0.87 \\
\hline $\mathrm{C}_{\text {org }}$ & 0.86 & -0.10 & 0.95 & -0.19 & 0.12 & 0.48 & -0.82 & 0.51 & 0.83 & -0.44 \\
\hline $\mathrm{Cd}$ & 0.30 & -0.77 & 0.83 & 0.31 & -0.34 & -0.17 & 0.88 & -0.28 & 0.50 & -0.64 \\
\hline $\mathrm{Cr}$ & -0.08 & 0.96 & -0.38 & -0.78 & 0.18 & -0.28 & -0.50 & -0.56 & 0.02 & -0.99 \\
\hline $\mathrm{Cu}$ & -0.02 & 0.99 & 0.51 & -0.86 & -0.55 & 0.54 & 0.73 & 0.05 & 0.91 & 0.33 \\
\hline $\mathrm{Ni}$ & 0.58 & 0.81 & -0.80 & -0.38 & 0.48 & -0.30 & 0.84 & 0.08 & 0.98 & 0.06 \\
\hline $\mathrm{Pb}$ & 0.56 & -0.12 & 0.95 & 0.27 & 0.35 & -0.03 & -0.22 & 0.90 & 0.19 & 0.81 \\
\hline $\mathrm{Zn}$ & 0.01 & 1.00 & -0.16 & -0.98 & -0.49 & -0.29 & -0.24 & 0.94 & 0.05 & 0.86 \\
\hline $\mathrm{Cd} \mathrm{CaCl}_{2}$ & -0.54 & -0.49 & -0.28 & -0.96 & 0.71 & -0.19 & 0.95 & -0.21 & -0.93 & 0.25 \\
\hline $\mathrm{Cr} \mathrm{CaCl} 2$ & 0.93 & -0.13 & - & - & 0.72 & 0.16 & 0.94 & -0.12 & - & - \\
\hline $\mathrm{Cu} \mathrm{CaCl} 2$ & 0.06 & 0.98 & 0.86 & 0.27 & 0.90 & -0.02 & 0.86 & 0.05 & 0.79 & 0.38 \\
\hline $\mathrm{Ni} \mathrm{CaCl} 2$ & 0.82 & 0.54 & -0.74 & -0.40 & 0.92 & -0.15 & 0.90 & -0.15 & -0.06 & 0.69 \\
\hline $\mathrm{Pb} \mathrm{CaCl}_{2}$ & -0.65 & -0.57 & 0.78 & 0.08 & 0.89 & -0.18 & 0.95 & -0.13 & 0.79 & 0.38 \\
\hline $\mathrm{Zn} \mathrm{CaCl}_{2}$ & -0.89 & 0.03 & 0.24 & -0.97 & 0.92 & -0.29 & 0.91 & -0.08 & -0.06 & 0.96 \\
\hline $\mathrm{Cd} \mathrm{Na}{ }_{2}$ EDTA & 0.92 & -0.40 & 0.93 & -0.30 & -0.12 & 0.96 & 0.85 & 0.45 & 0.77 & 0.17 \\
\hline $\mathrm{Cr} \mathrm{Na}{ }_{2}$ EDTA & 0.95 & -0.09 & 0.43 & 0.85 & 0.05 & 0.67 & 0.88 & 0.34 & 0.96 & -0.27 \\
\hline $\mathrm{Cu} \mathrm{Na}{ }_{2}$ EDTA & 0.94 & 0.33 & 0.63 & 0.70 & -0.12 & 0.97 & 0.14 & 0.50 & 1.00 & -0.07 \\
\hline $\mathrm{Ni} \mathrm{Na}{ }_{2}$ EDTA & 1.00 & 0.06 & -0.47 & 0.88 & -0.20 & 0.87 & 0.92 & 0.08 & 0.98 & -0.11 \\
\hline $\mathrm{Pb} \mathrm{Na}{ }_{2}$ EDTA & 0.07 & -0.90 & 0.73 & -0.68 & 0.06 & 0.83 & -0.16 & 0.80 & 0.97 & -0.23 \\
\hline $\mathrm{Zn} \mathrm{Na}{ }_{2}$ EDTA & 0.06 & 0.77 & 0.91 & 0.27 & -0.14 & 0.78 & 0.45 & 0.82 & 0.99 & -0.09 \\
\hline Total variance $\%$ & 50.1 & 34.9 & 51.1 & 38.2 & 35.1 & 21.9 & 56.9 & 20.7 & 57.2 & 28.6 \\
\hline $\begin{array}{l}\text { Cumulative } \\
\text { variance } \%\end{array}$ & 50.1 & 85.1 & 51.1 & 89.3 & 35.1 & 56.9 & 56.9 & 77.6 & 57.2 & 85.8 \\
\hline
\end{tabular}

Factor loadings exceeding $>0.6$ or $<-0.6$ are shown in bold; - not taken for PC analysis. 


\subsection{Geochemical Fractionation Indices}

While the focus of our study concentrated on the determination of mobile and bioavailable PHE contents in agricultural soils, we also applied geochemical fractionation indices in our studies. The values of the calculated mobility factor (MF) for individual PHEs (Table 5) were the highest for Cd and $\mathrm{Zn}$ in all the Regions, as well as for Co in the Opolskie: to put it precisely, the MF values were equal to the following proportions: Opolskie: Cd 31.1\%, Zn 31.0\%, and Co 13.8\%; Slaskie: Cd 30.6\% and Zn 23.7\%; Małopolskie: Cd 31.5\%; Świętokrzyskie: Cd 32.0\% and Zn 13.0\%; and Podkarpackie: $\mathrm{Zn} \mathrm{37.1 \%} \mathrm{and} \mathrm{Cd} \mathrm{36.7 \% .} \mathrm{The} \mathrm{high} \mathrm{values} \mathrm{of} \mathrm{the} \mathrm{MF} \mathrm{factor} \mathrm{indicated} \mathrm{that} \mathrm{the} \mathrm{respective} \mathrm{PHEs,} \mathrm{found} \mathrm{in}$ the described locations, were the most mobile among the investigated elements, showing potential threat to biota, surface, and groundwater contamination [41].

Table 5. The mobility factor (MF) values of individual PHEs of the agricultural soils in the Regions of southern Poland.

\begin{tabular}{cccccc}
\hline MF & $\begin{array}{c}\text { Opolskie } \\
(\boldsymbol{n}=\mathbf{4})\end{array}$ & $\begin{array}{c}\text { Śląskie } \\
(\boldsymbol{n}=\mathbf{4})\end{array}$ & $\begin{array}{c}\text { Małopolskie } \\
(\boldsymbol{n}=\mathbf{1 2})\end{array}$ & $\begin{array}{c}\text { Świętokrzyskie } \\
(\boldsymbol{n}=\mathbf{6})\end{array}$ & $\begin{array}{c}\text { Podkarpackie } \\
(\boldsymbol{n}=\mathbf{4})\end{array}$ \\
\hline $\mathrm{As}$ & 8.26 & 4.76 & 0.99 & 0.99 & 1.96 \\
$\mathrm{Cd}$ & 31.1 & 30.6 & 31.5 & 32.0 & 36.7 \\
$\mathrm{Co}$ & 13.8 & 9.09 & 8.26 & 9.09 & 9.91 \\
$\mathrm{Cr}$ & 0.99 & 0.99 & 0.00 & 0.00 & 0.00 \\
$\mathrm{Cu}$ & 6.54 & 1.96 & 1.96 & 2.91 & 3.85 \\
$\mathrm{Ni}$ & 6.42 & 0.39 & 7.18 & 6.30 & 3.85 \\
$\mathrm{~Pb}$ & 0.00 & 0.00 & 0.00 & 0.00 & 0.00 \\
$\mathrm{Sb}$ & 2.91 & 2.91 & 2.91 & 4.76 & 4.76 \\
$\mathrm{Tl}$ & 6.54 & 2.91 & 3.85 & 1.96 & 2.91 \\
$\mathrm{Zn}$ & 31.0 & 23.7 & 9.09 & 13.0 & 37.1 \\
\hline
\end{tabular}

As to other PHEs found in the investigated Regions, the values of the MF factors were $<10 \%$, indicating low element mobility and high stability under specific soil conditions, even when high pseudototal PHE concentrations were determined [66]. The mobility of PHEs followed the next orders, according to the calculated MF values: Opolskie: $\mathrm{Cd}>\mathrm{Zn}>\mathrm{Co}>\mathrm{As}>\mathrm{Cu}>\mathrm{Tl}>\mathrm{Ni}>\mathrm{Sb}>\mathrm{Cr}>$ $\mathrm{Pb}$; Śląskie: $\mathrm{Cd}>\mathrm{Zn}>\mathrm{Co}>\mathrm{As}>\mathrm{Sb}>\mathrm{Tl}>\mathrm{Cu}>\mathrm{Cr}>\mathrm{Ni}>\mathrm{Pb}$; Małopolskie: $\mathrm{Cd}>\mathrm{Zn}>\mathrm{Co}>\mathrm{Ni}>$ $\mathrm{Tl}>\mathrm{Sb}>\mathrm{Cu}>\mathrm{As}>\mathrm{Cr}>\mathrm{Pb}$; Świętokrzyskie: $\mathrm{Cd}>\mathrm{Zn}>\mathrm{Co}>\mathrm{Ni}>\mathrm{Sb}>\mathrm{Cu}>\mathrm{Tl}>\mathrm{As}>\mathrm{Cr}>\mathrm{Pb}$; Podkarpackie: $\mathrm{Zn}>\mathrm{Cd}>\mathrm{Co}>\mathrm{Sb}>\mathrm{Cu}>\mathrm{Ni}>\mathrm{Tl}>\mathrm{As}>\mathrm{Cr}>\mathrm{Pb}$. In southern Poland, the highest MF values were identified for $\mathrm{Cd}(31.6 \%)$ and $\mathrm{Zn}(21.0 \%)$, indicating that those elements were the most mobile. Other PHEs followed the order: $\mathrm{Co}>\mathrm{Ni}>\mathrm{Tl}>\mathrm{As}>\mathrm{Sb}>\mathrm{Cu}>\mathrm{Cr}>\mathrm{Pb}$, while their MF values were $<10 \%$, indicating that those elements were not readily available under the existing soil conditions. The values of the calculated RAC index (Table 6) indicated that the investigated soils were characterized by very high ecological risks for $\mathrm{Cd}$ and $\mathrm{Zn}$ in the Podkarpackie Region, while high ecological risks were determined for $\mathrm{Cd}$ in the Opolskie, Ślaskie, Małopolskie, and Podkarpackie, with Zn in the Opolskie and Ślaskie. Medium ecological risks were established for Co in the Opolskie and Podkarpackie and for $\mathrm{Zn}$ in the Świętokrzyskie. Low ecological risks were identified for As, Cr, $\mathrm{Cu}, \mathrm{Ni}, \mathrm{Sb}$, and $\mathrm{Tl}$ in the Opolskie, for $\mathrm{As}, \mathrm{Co}, \mathrm{Cr}, \mathrm{Cu}, \mathrm{Ni}, \mathrm{Sb}$, and $\mathrm{Tl}$ in the Slaskie, for As, Co, Cu, Ni, $\mathrm{Sb}$, and $\mathrm{Tl}$ in the Małopolskie and Świętokrzyskie, and additionally for Zn in the Małopolskie. No ecological risk was identified for $\mathrm{Pb}$ in all the five Regions, or $\mathrm{Cr}$ in the Małopolskie, Świętokrzyskie, and Podkarpackie. The modified RAC index (mRAC) revealed a high potential of adverse effects in the investigated soils of the Podkarpackie and a medium potential of adverse effects in the Opolskie, Ślaskie, Małopolskie, and Świętokrzyskie, in reference to the contents of all the PHEs analyzed (Table 6). The factor described above took into consideration only the PHE content, bound with the exchangeable and acid soluble fraction of elements $\left(\mathrm{BCR}_{\mathrm{F} 1}\right.$ fraction of the BCR extraction procedure). Thus, we also used the ICF factor in our investigations that took into account the potentially mobile fractions of PHEs $\left(\mathrm{BCR}_{\mathrm{F} 1}-\mathrm{BCR} \mathrm{F}_{\mathrm{F} 3}\right.$ fractions of the $\mathrm{BCR}$ extraction procedure). The calculated values of the ICF factor 
(Table 7) arranged PHEs in the following decreasing order of potential adverse effect risks: Opolskie: $\mathrm{Pb}>\mathrm{Cd}>\mathrm{Zn}>\mathrm{Sb}>\mathrm{Cu}>\mathrm{Tl}>\mathrm{Ni}>\mathrm{Co}>\mathrm{As}>\mathrm{Cr}$; Śląskie: $\mathrm{Cd}>\mathrm{Pb}>\mathrm{Zn}>\mathrm{Sb}>\mathrm{Co}>\mathrm{As}>\mathrm{Ni}>\mathrm{Cu}>$ $\mathrm{Tl}>\mathrm{Cr}$; Małopolskie: $\mathrm{Cd}>\mathrm{Sb}>\mathrm{Pb}>\mathrm{Co}>\mathrm{Ni}>\mathrm{Cu}>\mathrm{Cr}>\mathrm{As}>\mathrm{Zn}>\mathrm{Tl}$; Świętokrzyskie: $\mathrm{Cd}>\mathrm{Pb}>$ $\mathrm{Co}>\mathrm{Sb}>\mathrm{Tl}>\mathrm{Ni}>\mathrm{Cu}>\mathrm{Zn}>\mathrm{As}>\mathrm{Cr}$; and Podkarpackie: $\mathrm{Cd}>\mathrm{Pb}>\mathrm{Sb}>\mathrm{Zn}>\mathrm{Cu}>\mathrm{Co}>\mathrm{Ni}>\mathrm{Tl}>$ As $>$ Cr. Finally, looking at the GCF factor (Table 7), the decreasing order of the Regions described by the potential adverse effect risks of all PHEs in the investigated soils was as follows: Opolskie $>$ Podkarpackie $>$ Świętokrzyskie $>$ Śląskie $>$ Małopolskie.

Table 6. Ecological risk of PHEs in soils, according to the risk assessment code (RAC) and modified RAC (mRAC) indices.

\begin{tabular}{|c|c|c|c|c|c|}
\hline RAC & $\begin{array}{l}\text { Opolskie } \\
(n=4)\end{array}$ & $\begin{array}{l}\text { Śląskie } \\
(n=4)\end{array}$ & $\begin{array}{l}\text { Małopolskie } \\
\quad(n=12)\end{array}$ & $\begin{array}{c}\text { Świętokrzyskie } \\
(n=6)\end{array}$ & $\begin{array}{l}\text { Podkarpackie } \\
\quad(n=4)\end{array}$ \\
\hline As & low & low & low & low & low \\
\hline $\mathrm{Cd}$ & high & high & high & high & very high \\
\hline Co & medium & low & low & low & medium \\
\hline $\mathrm{Cr}$ & low & low & no risk & no risk & no risk \\
\hline $\mathrm{Cu}$ & low & low & low & low & low \\
\hline $\mathrm{Ni}$ & low & low & low & low & low \\
\hline $\mathrm{Pb}$ & no risk & no risk & no risk & no risk & no risk \\
\hline $\mathrm{Sb}$ & low & low & low & low & low \\
\hline $\mathrm{Tl}$ & low & low & low & low & low \\
\hline $\mathrm{Zn}$ & high & high & low & medium & very high \\
\hline & medium & medium & medium & medium & medium \\
\hline mRAC & $\begin{array}{l}\text { potential of } \\
\text { adverse effect }\end{array}$ & $\begin{array}{l}\text { potential of } \\
\text { adverse effect }\end{array}$ & $\begin{array}{l}\text { potential of } \\
\text { adverse effect }\end{array}$ & $\begin{array}{l}\text { potential of } \\
\text { adverse effect }\end{array}$ & $\begin{array}{l}\text { potential of } \\
\text { adverse effect }\end{array}$ \\
\hline
\end{tabular}

Table 7. Potential adverse effect risks, according to the individual contamination factor (ICE) and global contamination factor (GCF) indices.

\begin{tabular}{cccccc}
\hline ICF & $\begin{array}{c}\text { Opolskie } \\
(\boldsymbol{n}=\mathbf{4})\end{array}$ & $\begin{array}{c}\text { Śląskie } \\
(\boldsymbol{n}=\mathbf{4})\end{array}$ & $\begin{array}{c}\text { Małopolskie } \\
(\boldsymbol{n}=\mathbf{1 2})\end{array}$ & $\begin{array}{c}\text { Świętokrzyskie } \\
(\boldsymbol{n}=\mathbf{6})\end{array}$ & $\begin{array}{c}\text { Podkarpackie } \\
(\boldsymbol{n}=\mathbf{4})\end{array}$ \\
\hline $\mathrm{As}$ & 1.00 & 1.00 & 0.59 & 0.47 & 0.72 \\
$\mathrm{Cd}$ & 32.3 & 19.0 & 9.00 & 24.0 & 49.0 \\
$\mathrm{Co}$ & 1.13 & 1.22 & 1.44 & 3.00 & 1.44 \\
$\mathrm{Cr}$ & 0.64 & 0.35 & 0.72 & 0.35 & 0.49 \\
$\mathrm{Cu}$ & 4.56 & 0.82 & 0.79 & 1.00 & 2.23 \\
$\mathrm{Ni}$ & 1.70 & 0.89 & 0.89 & 1.17 & 1.04 \\
$\mathrm{~Pb}$ & 49.0 & 3.00 & 1.59 & 3.76 & 15.7 \\
$\mathrm{Sb}$ & 4.88 & 1.94 & 3.17 & 3.00 & 7.33 \\
$\mathrm{Tl}$ & 2.70 & 0.75 & 0.32 & 1.22 & 1.04 \\
$\mathrm{Zn}$ & 7.17 & 2.16 & 0.52 & 0.79 & 6.14 \\
$\mathrm{GCF}$ & $\mathbf{1 0 5}$ & $\mathbf{3 1 . 1}$ & $\mathbf{1 9 . 0}$ & $\mathbf{3 8 . 8}$ & $\mathbf{8 5 . 1}$ \\
\hline
\end{tabular}

\section{Conclusions}

The following conclusions were derived, based on the investigations of agricultural soils samples taken from the depth of $0-25 \mathrm{~cm}$ each, particularly where edible plants were cultivated in southern Poland. The measured $\mathrm{pH}$ values classified the investigated samples of arable soils as neutral (Opolskie and Śląskie) and slightly acidic (Małopolskie, Świętokrzyskie, and Podkarpackie). The highest pseudototal contents of PHEs were stated in Ślaskie and Małopolskie regions for $\mathrm{Cd}, \mathrm{Cu}, \mathrm{Pb}$, and $\mathrm{Zn}$ that can be related with the geochemistry of these regions and particular soil properties. None of PHEs exceeded the permissible content, in reference to the Polish soil quality standards. However, considering the Canadian soil quality guidelines for the protection of environmental and human health, it was revealed that contents of $\mathrm{Cd}, \mathrm{Cu}, \mathrm{Pb}$, and $\mathrm{Zn}$ in the Ślaskie and $\mathrm{Cd}$ and $\mathrm{Zn}$ in the Małopolskie Regions were higher than recommended. However, calculated geochemical fractionation indices 
revealed that in southern Poland $\mathrm{Cd}$ and $\mathrm{Zn}$ were the most mobile according to mobility factor (MF) values: $\mathrm{Cd}(31.6 \%)$ and $\mathrm{Zn}(21.0 \%)$. Other PHEs were not readily available under the existing soil conditions their MF values were $<10 \%$. Based on the risk assessment code (RAC) values of very high $\mathrm{Cd}$ and $\mathrm{Zn}$ ecological risks were determined in the Podkarpackie and a high Cd ecological risk in the Opolskie, Śląskie, Małopolskie, and Podkarpackie Regions, as well as a high Zn risk in the Opolskie and Ślaskie. The modified risk assessment code index (mRAC) values revealed a high potential of adverse effects in the soils of the Podkarpackie and a medium potential of adverse effects in the Opolskie, Ślaskie, Małopolskie, and Świętokrzyskie, in reference to contents of all the PHEs analyzed. The decreasing order of the potential adverse effect risk, in reference to the single geochemical fractionation index (ICF), was as follows: Opolskie: $\mathrm{Pb}>\mathrm{Cd}>\mathrm{Zn}>\mathrm{Sb}>\mathrm{Cu}>\mathrm{Tl}>\mathrm{Ni}>\mathrm{Co}>\mathrm{As}>\mathrm{Cr}$; Śląskie: $\mathrm{Cd}>\mathrm{Pb}>$ $\mathrm{Zn}>\mathrm{Sb}>\mathrm{Co}>\mathrm{As}>\mathrm{Ni}>\mathrm{Cu}>\mathrm{Tl}>\mathrm{Cr}$; Małopolskie: $\mathrm{Cd}>\mathrm{Sb}>\mathrm{Pb}>\mathrm{Co}>\mathrm{Ni}>\mathrm{Cu}>\mathrm{Cr}>\mathrm{As}>\mathrm{Zn}>$ Tl; Świętokrzyskie: $\mathrm{Cd}>\mathrm{Pb}>\mathrm{Co}>\mathrm{Sb}>\mathrm{Tl}>\mathrm{Ni}>\mathrm{Cu}>\mathrm{Zn}>\mathrm{As}>\mathrm{Cr}$, and Podkarpackie: $\mathrm{Cd}>\mathrm{Pb}>$ $\mathrm{Sb}>\mathrm{Zn}>\mathrm{Cu}>\mathrm{Co}>\mathrm{Ni}>\mathrm{Tl}>\mathrm{As}>\mathrm{Cr}$. The global geochemical fractionation index (GCF), describing the potential adverse effect risks of all the PHEs were ordered decreasingly as follows: Opolskie $>$ Podkarpackie $>$ Świętokrzyskie $>$ Śląskie $>$ Małopolskie. The probable source of the detected ecological risk of $\mathrm{Cd}$ and $\mathrm{Zn}$, in the regions where it was not caused by the geological background, was phosphate mineral fertilizers applications in agriculture. It has to be stated in conclusion that, apart from the mobile and potentially mobile contents of the elements determined under the extraction procedures, the bioavailability strongly depended on soil properties and the pseudototal concentration of individual elements.

Author Contributions: Conceptualization, A.G.-K. and A.B.; Data curation, A.G.-K. and K.M.-K.; Formal analysis, A.G.-K.; Funding acquisition, A.G.-K.; Investigation, A.G.-K., A.B., K.M.-K. and T.C.; Methodology, A.G.-K., A.B. and T.C.; Project administration, A.G.-K.; Resources, A.G.-K.; Software, A.G.-K. and A.B.; Supervision, A.G.-K.; Validation, A.G.-K.; Visualization, A.G.-K.; Writing—original draft, A.G.-K. and A.B.; Writing—review and editing, A.G.-K.

Funding: This research was funded by Akademia Górniczo-Hutnicza im. Stanislawa Staszica: Dean's Grant No. 15.11.140.357 and Akademia Górniczo-Hutnicza im. Stanislawa Staszica: Statutory Research Grant No. 11.11.140.199.

Conflicts of Interest: The authors declare no conflict of interest.

\section{References}

1. Bini, C.; Bech, J. PHEs, Environment and Human Health: Potentially Harmful Elements in the Environment and the Impact on Human Health; Springer: Heidelberg, Germany, 2014.

2. Sparks, D.L. Toxic metals in the environment: The role of surface. Elements 2005, 1, 193-196. [CrossRef]

3. Skalnaya, M.G.; Skalny, A.V. Essential Trace Elements in Human Health: A Physician's View; Publishing House of Tomsk State University: Tomsk, Russia, 2018.

4. Antibachi, D.; Kelepertzis, E.; Kelepertsis, A. Heavy metals in agricultural soils of the Mouriki-Thiva area (Central Greece) and environmental impact implications. Soil Sediment. Contam. 2012, 21, 434-450. [CrossRef]

5. Adriano, D.C. Trace Elements in the Terrestrial Environment: Biogeochemistry, Bioavailability and Risks of Metals, 2nd ed.; Springer: New York, NY, USA, 2001.

6. Shi, T.; Ma, J.; Wu, X.; Ju, T.; Lin, X.; Zhang, Y.; Li, X.; Gong, Y.; Hou, H.; Zhao, L.; et al. Inventories of heavy metal inputs and outputs to and from agricultural soils: A review. Ecotox. Environ. Saf. 2018, 164, 118-124. [CrossRef] [PubMed]

7. Sofianska, E.; Michailidis, K. Chemical assessment and fractionation of some heavy metals and arsenic in agricultural soils of the mining affected Drama plain, Macedonia, northern Greece. Environ. Monit. Assess. 2015, 187, 101. [CrossRef] [PubMed]

8. Sungur, A.; Soylak, M.; Yilmaz, E.; Yilmaz, S.; Ozcan, H. Characterization of heavy metal fractions in agricultural soils by sequential extraction procedure: The relationship between soil properties and heavy metal fractions. Soil Sediment Contam. 2015, 24, 1-15. [CrossRef] 
9. Shang, W.; Tang, Q.; Zheng, L.; Cheng, H. Chemical forms of heavy metals in agricultural soils affected by coal mining in the Linhuan subsidence of Huaibei Coalfield, Anhui Province, China. Environ. Sci. Pollut. R. 2016, 23, 23683-23693. [CrossRef]

10. Tóth, G.; Hermann, T.; Da Silva, M.R.; Montanarella, L. Heavy metals in agricultural soils of the European Union with implications for food safety. Environ. Int. 2016, 88, 299-309. [CrossRef]

11. Da Silva, F.B.V.; Nascimento, C.W.A.; Araújo, P.R.M.; da Silva, F.L.; Lima, L.H.V. Soil contamination by metals with high ecological risk in urban and rural areas. Int. J. Environ. Sci. Technol. 2017, 14, 553-562. [CrossRef]

12. Doabi, S.A.; Karami, M.; Afyuni, M.; Yeganeh, M. Pollution and health risk assessment of heavy metals in agricultural soil, atmospheric dust and major food crops in Kermanshah province, Iran. Ecotox. Environ. Saf. 2018, 163, 153-164. [CrossRef]

13. El-Radaideh, N.M.; Al-Kareem Al-Taani, A.A. Geo-environmental study of heavy metals of the agricultural highway soils, NW Jordan. Arab. J. Geosci. 2018, 11, 787. [CrossRef]

14. Cai, L.M.; Wang, Q.S.; Wen, H.H.; Luo, J.; Wang, S. Heavy metals in agricultural soils from a typical township in Guangdong Province, China: Occurrences and spatial distribution. Ecotox. Environ. Saf. 2019, 168, 184-191. [CrossRef] [PubMed]

15. Huang, Y.; Wang, L.; Wang, W.; Li, T.; He, Z.; Yang, X. Current status of agricultural soil pollution by heavy metals in China: A meta-analysis. Sci. Total Environ. 2019, 651, 3034-3042. [CrossRef] [PubMed]

16. Keshavarzi, A.; Kumar, V. Spatial distribution and potential ecological risk assessment of heavy metals in agricultural soils of Northeastern Iran. Geol. Ecol. Landsc. 2019, 1-17. [CrossRef]

17. Gruszecka-Kosowska, A.; Baran, A.; Wdowin, M.; Mazur-Kajta, K.; Czech, T. The contents of the Potentially Harmful Elements in the arable soils of southern Poland, with the assessment of ecological and health risks: A case study. Environ. Geochem. Health 2019, 1-24. [CrossRef] [PubMed]

18. Santoro, A.; Held, A.; Linsinger, T.P.J.; Perez, A.; Ricci, M. Comparison of total and aqua regia extractability of heavy metals in sewage sludge: The case study of the certified reference material. Trends Anal. Chem. 2017, 8, 34-40. [CrossRef]

19. Milićević, T.; Relić, R.; Škrivanj, S.; Tesić, Ž.; Popović, A. Assessment of major and trace element bioavailability in vineyard soil applying different single extraction procedures and pseudo-total digestion. Chemosphere 2017, 171, 284-293. [CrossRef]

20. Meers, E.; Samson, R.; Tack, F.M.G.; Ruttens, A.; Vangegehuchte, M.; Vangronsveld, J.; Verloo, M.G. Phytoavailability assessment of heavy metals in soils by single extractions and accumulation by Phaseolus vulgaris. Environ. Exp. Bot. 2007, 60, 385-396. [CrossRef]

21. Harmsen, J. Measuring bioavailability: From a scientific approach to standard methods. J. Environ. Qual. 2007, 36, 1420-1428. [CrossRef]

22. Harmsen, J. Soil Quality_Requirements and Guidance for the Selection and Application of Methods for the Assessment of Bioavailability of Contaminants in Soil and Soil Materials; Werkgroep ISO/DIS17402 Soil Quality: Geneva, Switzerland, 2008.

23. Kim, R.Y.; Yoon, J.K.; Kim, T.S.; Yang, J.E.; Owens, G.; Kim, K.R. Bioavailability of heavy metals in soils: Definitions and practical implementation-A critical review. Environ. Geochem. Health 2015, 37, 1041-1061. [CrossRef]

24. Nemati, K.; Bakar, N.K.A.; Abas, M.R. Investigations of heavy metals mobility in shrimp aquaculture sludge-Comparison of two sequential extraction procedures. Microchem. J. 2009, 91, 227-231. [CrossRef]

25. Shaheen, S.M.; Rinklebe, J. Geochemical fractions of chromium, copper, and zinc and their vertical distribution in floodplain soil profiles along the Central Elbe. Geoderma 2014, 228, 152-159. [CrossRef]

26. Tessier, A.; Campbell, P.G.C.; Bisson, M. Sequential extraction procedure for the speciation of particulate trace metals. Anal. Chem. 1979, 51, 844-851. [CrossRef]

27. Rauret, G. Extraction procedures for the determination of heavy metals in contaminated soil and sediments. Talanta 1998, 46, 449-455. [CrossRef]

28. Labaz, B.; Kabala, C.; Waroszewski, J. Ambient geochemical baselines for trace elements in Chernozems-Approximation of geochemical soil transformation in an agricultural area. Environ. Monit. Assess. 2019, 191, 19.

29. EPA. Method 6020B: Inductively Coupled Plasma-Mass Spectrometry. Revision 2; USEPA: Washington, DC, USA, 1998. 
30. PN-EN ISO 17294-2:2006. Water Quality—Use of Inductively Induced Plasma Mass Spectrometry (ICP-MS)—Part 2: Determination of 62 Elements; Polish Committee for Standardization: Warsaw, Poland, 2006.

31. Quevauviller, P.; Rauret, G.; Lopez-Sanchez, J.F.; Rubio, R.; Ure, A.; Muntau, H. Certification of trace metal extractable contents in a sediment reference material (CRM 601) following a three step sequential extraction procedure. Sci. Total Environ. 1997, 205, 223-234. [CrossRef]

32. Pueyo, M.; López-Sánchez, J.F.; Rauret, G. Assessment of $\mathrm{CaCl}_{2}, \mathrm{NaNO}_{3}$ and $\mathrm{NH}_{4} \mathrm{NO}_{3}$ extraction procedures for the study of $\mathrm{Cd}, \mathrm{Cu}, \mathrm{Pb}$ and $\mathrm{Zn}$ extractability in contaminated soils. Anal. Chim. Acta 2004, 504, 217-226. [CrossRef]

33. Wieczorek, J.; Baran, A.; Urbański, K.; Mazurek, K.; Klimkowicz-Pawlas, A. Assessment of the pollution and ecological risk of lead and cadmium in soils. Environ. Geochem. Health 2018, 40, 2325-2342. [CrossRef]

34. PN-EN ISO 17294-1:2007. Water Quality_Induced Plasma Mass Spectrometry (ICP-MS)—Part 1: General Guidelines; Polish Committee for Standardization: Warsaw, Poland, 2007.

35. PN-EN ISO 11885:2009. Water Quality_Determination of Selected Elements by Inductively Coupled Plasma Optical Emission Spectrometry (ICP-OES); Polish Committee for Standardization: Warsaw, Poland, 2009.

36. Barona, A.; Aranguiz, I.; Elías, A. Assessment of metal extraction, distribution and contamination in surface soils by a 3-step sequential extraction procedure. Chemosphere 1999, 39, 1911-1922. [CrossRef]

37. Saeedi, M.; Jamshidi-Zanjani, A. Development of a new aggregative index to assess potential effect of metals pollution in aquatic sediments. Ecol. Indic. 2015, 58, 235-243. [CrossRef]

38. Regulation of the Minister of the Environment of 1 September 2016 on the conduct of the assessment of contamination of the surface of the earth. J. Laws 2016, 1396, 1-86.

39. Canadian soil quality guidelines for the protection of environmental and human health: Summary tables. Updated 7.0. In Canadian Environmental Quality Guidelines, 1999; Canadian Council of Ministers of the Environment: Winnipeg, MB, Canada, 2007.

40. Gasparatos, D.; Mavromati, G.; Kotsovilis, P.; Massas, I. Fractionation of heavy metals and evaluation of the environmental risk for the alkaline soils of the Thriassio plain: A residential, agricultural, and industrial area in Greece. Environ. Earth Sci. 2015, 74, 1099-1108. [CrossRef]

41. Iwegbue, C.M.A. Chemical fractionation and mobility of heavy metals in soils in the vicinity of asphalt plants in Delta State, Nigeria. Environ. Forensics 2013, 14, 248-259. [CrossRef]

42. Singh, K.P.; Mohan, D.; Singh, V.K.; Malik, A. Studies on distribution and fractionation of heavy metals in Gomti river sediments-A tributary of the Ganges, India. J. Hydrol. 2005, 312, 14-27. [CrossRef]

43. Naji, A.; Ismail, A.; Ismail, A.R. Chemical speciation and contamination assessment of Zn and Cd by sequential extraction in surface sediment of Klang River, Malaysia. Microchem. J. 2010, 95, 285-292. [CrossRef]

44. Håkanson, L. An ecological risk index for aquatic pollution control. A sedimentological approach. Water Res. 1980, 14, 975-1001. [CrossRef]

45. Gong, Q.; Deng, J. Calculating pollution indices by heavy metals in ecological geochemistry assessment and as case study in parks of Beijing. J. China Univ. Geosci. 2008, 19, 230-241.

46. Chai, L.; Li, H.; Yang, Z.; Min, X.; Liao, Q.; Liu, Y.; Men, S.; Yan, Y.; Xu, J. Heavy metals and metalloids in the surface sediments of the Xiangjiang River, Hunan, China: Distribution, contamination, and ecological risk assessment. Environ. Sci. Pollut. R. 2017, 24, 874-885. [CrossRef]

47. Liu, Y.; Wang, Q.; Zhuang, W.; Yuan, Y.; Jiao, K.; Wang, M.; Chen, Q. Calculation of thallium's toxicity coefficient in the evaluation of potential ecological risk index: A case study. Chemosphere 2018, 194, 562-569. [CrossRef]

48. Wang, N.; Wang, A.; Kong, L.; He, M. Calculation and application of Sb toxicity coefficient for potential ecological risk assessment. Sci. Total Environ. 2018, 610, 167-174. [CrossRef]

49. Chemical Monitoring of Arable Soils IUNG Institute of Soil Science and Plant Cultivation in Puławy, Main Inspectorate of Environmental Protection. 2017. Available online: http://www.gios.gov.pl/chemizm_gleb/ index.php?mod=monit (accessed on 19 September 2012).

50. Loska, K.; Wiechuła, D.; Korus, I. Metal contamination of farming soils affected by industry. Environ. Int. 2004, 30, 159-165. [CrossRef]

51. Pająk, M.; Błońska, E.; Szostak, M.; Gąsiorek, M.; Pietrzykowski, M.; Urban, O.; Derbis, P. Restoration of vegetation in relation to soil properties of spoil heap heavily contaminated with heavy metals. Water Air Soil Poll. 2018, 229, 392. [CrossRef] [PubMed] 
52. Piekut, A.; Baranowska, R.; Marchwińska-Wyrwał, E.; Ćwielag-Drabek, M.; Hajok, I.; Dziubanek, G.; Grochowska-Niedworok, E. Is the soil quality monitoring an effective tool in consumers' protection of agricultural crops from cadmium soil contamination?-A case of the Ślaskie region (Poland). Environ. Monit. Assess. 2018, 190, 25. [CrossRef] [PubMed]

53. Waroszewski, J.; Sprafke, T.; Kabała, C.; Kobierski, M.; Kierczak, J.; Musztyfaga, E.; Loba, A.; Mazurek, R.; Łabaz, B. Tracking textural, mineralogical and geochemical signatures in soils developed from basalt-derived materials covered with loess sediments (SW Poland). Geoderma 2019, 337, 983-997. [CrossRef]

54. Krzaklewski, W.; Barszcz, J.; Małek, S.; Kozioł, K.; Pietrzykowski, M. Contamination of forest soils in the vicinity of the sedimentation pond after zinc and lead ore flotation (in the region of Olkusz, southern Poland). Water Air Soil Poll. 2004, 159, 151-164. [CrossRef]

55. Baran, A.; Czech, T.; Wieczorek, J. Chemical properties and toxicity of soils contaminated by mining activity. Ecotoxicology 2014, 2, 1234-1244.

56. Baran, A.; Wieczorek, J. Application of geochemical and ecotoxicity indices for assessment of heavy metals content in soils. Arch. Environ. Prot. 2015, 41, 54-63. [CrossRef]

57. Baran, A.; Wieczorek, J.; Mazurek, R.; Urbański, K.; Klimkowicz-Pawlas, A. Potential ecological risk assessment and predicting zinc accumulation in soils. Environ. Geochem. Health. 2018, 40, 435-450. [CrossRef]

58. Mazurek, R.; Kowalska, J.B.; Gąsiorek, M.; Zadrożny, P. Pollution indices as comprehensive tool for evaluation of the accumulation and provenance of potentially harmful elements in soils in Ojców National Park. J. Geochem. Explor. 2019, 201, 13-30. [CrossRef]

59. Mazurek, R.; Kowalska, J.; Gąsiorek, M.; Zadrożny, P.; Józefowska, A.; Zaleski, T.; Kepka, W.; Tymczuk, W.; Orłowska, K. Assessment of heavy metals contamination in surface layers of Roztocze National Park forest soils (SE Poland) by indices of pollution. Chemosphere 2017, 168, 839-850. [CrossRef]

60. Gałuszka, A.; Migaszewski, Z.M.; Dołęowska, S.; Michalik, A. Geochemical anomalies of trace elements in unremediated soils of Mt. Karczówka, a historic lead mining area in the city of Kielce, Poland. Sci. Total Environ. 2018, 639, 397-405. [CrossRef]

61. Lis, J.; Pasieczna, A. Geochemical Atlas of Kraków and Environs, 1:100,000; Państwowy Instytut Geologiczny: Warszawa, Poland, 1995.

62. Lis, J.; Pasieczna, A. Geochemical Atlas of Upper Silesia, 1:100,000; Państwowy Instytut Geologiczny: Warszawa, Poland, 1995.

63. Pasieczna, A.; Fajfer, J.; Strzemińska, K. Szczegółowa mapa geochemiczna Górnego Ślaska w skali 1:25 000 Arkusz Zabrze M-34-62-B-a: Detailed Geochemical Map of Upper Silesia in the Scale of 1:25,000 Zabrze sheet M-34-62-B-a; Państwowy Instytut Geologiczny: Warszawa, Poland, 2016.

64. Pinto, E.; Almeida, A.A.; Ferreira, I.M.P.L.V.O. Assessment of metal(loid)s phytoavailability in intensive agricultural soils by the application of single extractions to rhizosphere soil. Ecotox. Environ. Saf. 2015, 113, 418-424. [CrossRef] [PubMed]

65. Liu, G.; Tao, L.; Liu, X.; Hou, J.; Wang, A.; Li, R. Heavy metals speciation and pollution of agricultural soils along Jishui River in non-ferrous metal mine area in Jiangxi Province, China. J. Geochem. Explor. 2013, 132, 156-163. [CrossRef]

66. Lei, M.; Zhang, Y.; Khan, S.; Qin, P.F.; Liao, B.H. Pollution, fractionation, and mobility of Pb, Cd, Cu, and Zn in garden and paddy soils from a $\mathrm{Pb} / \mathrm{Zn}$ mining area. Environ. Monit. Assess. 2010, 168, 215-222. [CrossRef] [PubMed]

(C) 2019 by the authors. Licensee MDPI, Basel, Switzerland. This article is an open access article distributed under the terms and conditions of the Creative Commons Attribution (CC BY) license (http://creativecommons.org/licenses/by/4.0/). 